1996

\title{
Excavation of the San Pedro Acequia on the Grounds of the San Antonio Housing Authority
}

David L. Nickels

I. Waynne Cox

Center for Archaeological Research

Connie Gibson

Center for Archaeological Research

Follow this and additional works at: https://scholarworks.sfasu.edu/ita

Part of the American Material Culture Commons, Archaeological Anthropology Commons, Environmental Studies Commons, Other American Studies Commons, Other Arts and Humanities Commons, Other History of Art, Architecture, and Archaeology Commons, and the United States History Commons

Tell us how this article helped you.

This Article is brought to you for free and open access by the Center for Regional Heritage Research at SFA ScholarWorks. It has been accepted for inclusion in Index of Texas Archaeology: Open Access Gray Literature from the Lone Star State by an authorized editor of SFA ScholarWorks. For more information, please contact cdsscholarworks@sfasu.edu. 


\section{Excavation of the San Pedro Acequia on the Grounds of the San Antonio Housing}

Authority

\section{Creative Commons License}

\section{(c) (1) \&}

This work is licensed under a Creative Commons Attribution-NonCommercial 4.0 International License 


\section{Excavation of the San Pedro Acequia on the Grounds of the San Antonio Housing Authority}
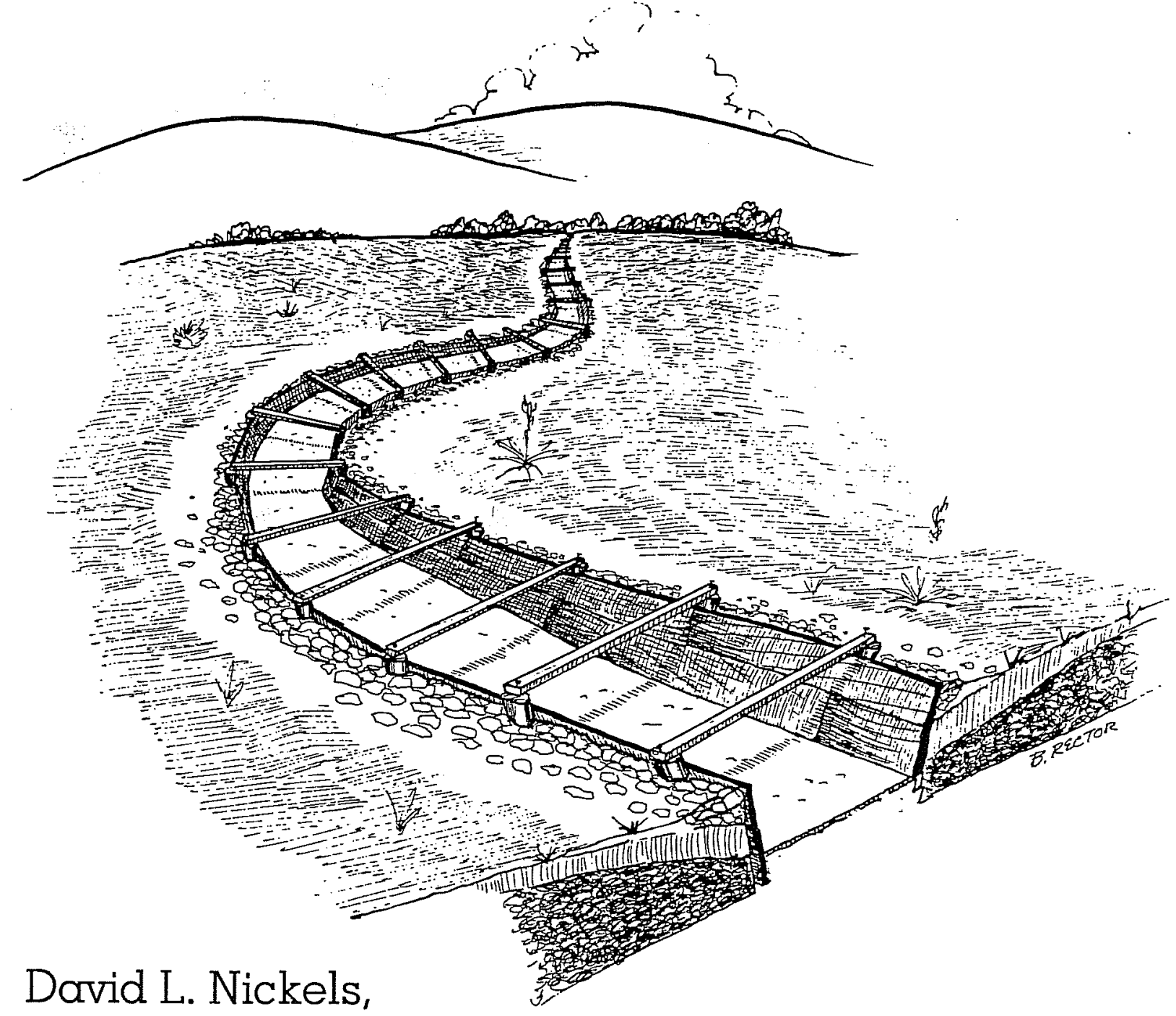

I. Waynne Cox, and Connie Gibson

with contributions by

Barbara A. Meissner and Barbara M. Winsborough

Center for Archaeological Research The University of Texas at San Antonio Archueological Survey Report, No. 243 



\section{Excavation of the San Pedro Acequia on the Grounds of the San Antonio Housing Authority}

\section{David L. Nickels, I. Waynne Cox, and Connie Gibson with contributions by \\ Barbara A. Meissner and Barbara M. Winsborough}

Robert J. Hard, Principal Investigator

C. Britt Bousman, Co-principal Investigator

Texas Antiquities Committee Permit No. 1429

Ocopyright

Center for Archaeological Research

The University of Texas at San Antonio

Archaeological Survey Report, No. 243 
The following information is provided in accordance with the General Rules of Practice and Procedure, Chapter 41.11 (Investigative Reports), Texas Antiquities Committee:

1. Type of investigation: Machine trenching and hand excavation

2. Project name: San Antonio Housing Authority (SAHA) Administration Building

3. County: Bexar

4. Principal investigator: Robert J. Hard; co-principal investigator: C. Britt Bousman

5. Name and location of sponsoring agency: City of San Antonio, 818 South Flores, San Antonio, Texas 78204

6. Texas Antiquities Permit No.: 1429

7. Published by the Center for Archaeological Research, The University of Texas at San Antonio, Texas 78249-0658, 1996

A list of publications offered by the Center for Archaeological Research is available. Call (210) 458-4378; write to the Center for Archaeological Research, The University of Texas at San Antonio, 6900 N. Loop 1604 W., San Antonio, Texas 78249-0658; e-mail to car@lonestar.utsa.edu.; or on the world-wide web at http://www.csbs.utsa.edu/org/car/index.htm. 


\begin{abstract}
In July and August 1994, the Center for Archaeological Research (CAR) of The University of Texas at San Antonio conducted excavations to determine the location and construction methods of the San Pedro Acequia (41BX337) on the grounds of the San Antonio Housing Authority (SAHA) in southern San Antonio, Texas. CAR was contracted by SAHA to conduct the excavations prior to construction which could impact the acequia. Testing of the site was completed in October 1994.

As a result of shovel testing, Gradall and backhoe operations, and hand excavation of small units, CAR identified the acequia and exposed it for mapping in profile and plan. For the first time, investigators were able to document wood lining of the acequia. The channel contained a dense concentration of latenineteenth- and early twentieth-century artifacts. Soil samples were taken for diatom analysis. No further documentation of the architectural design and construction of the wood lining in the project area is warranted.
\end{abstract}




\section{Contents}

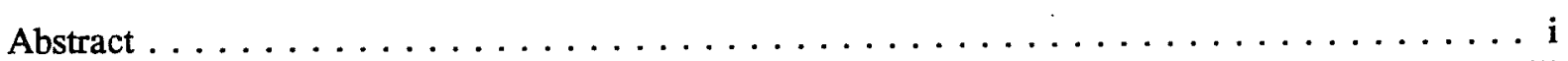

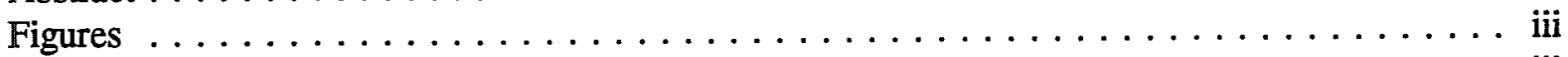

Tables $\ldots \ldots \ldots \ldots \ldots \ldots \ldots \ldots \ldots \ldots \ldots \ldots \ldots \ldots \ldots \ldots$ iii

Acknowledgments $\ldots \ldots \ldots \ldots \ldots \ldots \ldots \ldots \ldots \ldots \ldots \ldots \ldots$ iv

Introduction

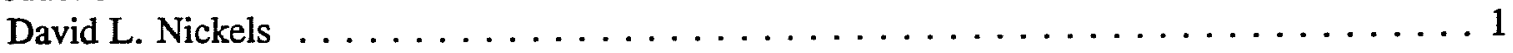

History of the San Pedro Acequia

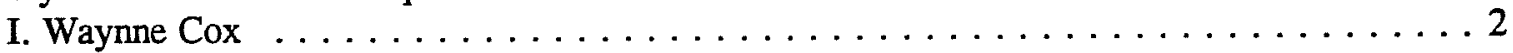

Acequia Construction

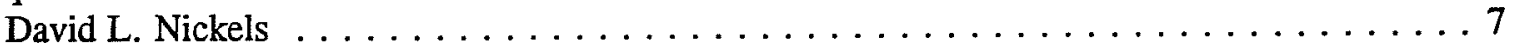

San Antonio Housing Authority Property History

David L. Nickels . . . . . . . . . . . . . . . . . . . 8

Previous Archaeological Investigations

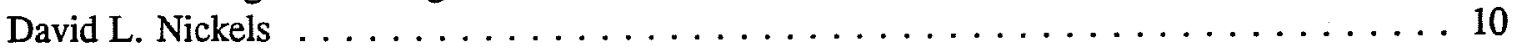

Methods and Results

David L. Nickels . . . . . . . . . . . . . . . . . . . . . . 12

Artifact Analysis

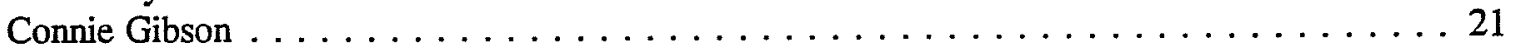

Faunal Analysis

Barbara A. Meissner . . . . . . . . . . . . . . . . . . 40

Diatom Analysis

David L. Nickels . . . . . . . . . . . . . . . . . . . . 42

Conclusions and Recommendations

David L. Nickels . . . . . . . . . . . . . . . . . . . . . 43

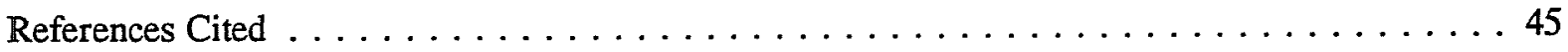

Appendix A: Faunal Remains . . . . . . . . . . . . . . . . . . . . 48

Appendix B: Diatom Analysis of Material from the San Pedro Acequia

Barbara $M$. Winsborough . . . . . . . . . . . . . . . . 50 


\section{Figures}

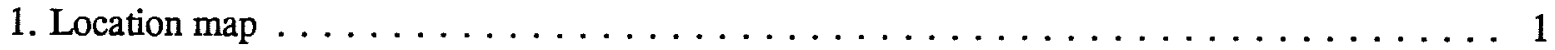

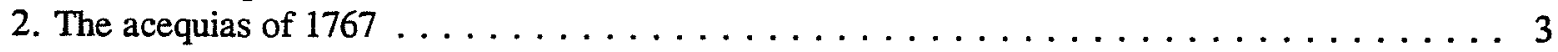

3. Archaeological investigations on the SAHA property and route of the San Pedro Acequia . . . 11

4. Hand-excavation Units A and B, within Trench 2, July $1994 \ldots \ldots \ldots \ldots$

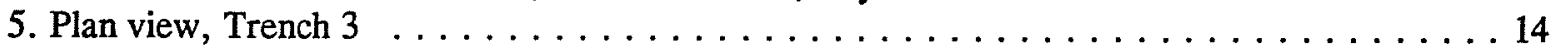

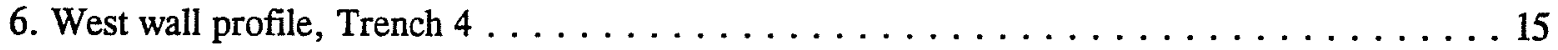

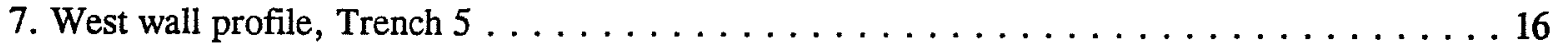

8. North wall profile, Excavation Unit A . . . . . . . . . . . . . . . 18

9. South wall profile, Excavation Unit B . . . . . . . . . . . . . . . . . . . . . 19

10. Artistic reconstruction of the San Pedro Acequia, based on archaeological data . . . . . 20

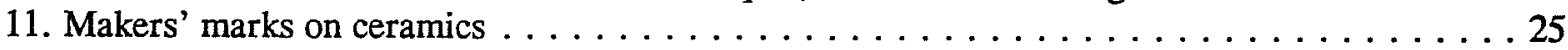

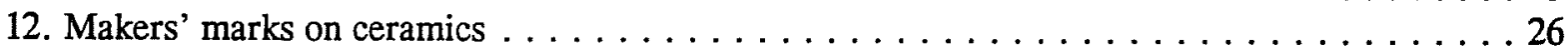

13. Decorated whiteware . . . . . . . . . . . . . . . . . . 27

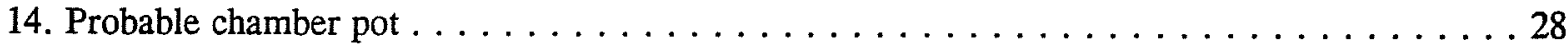

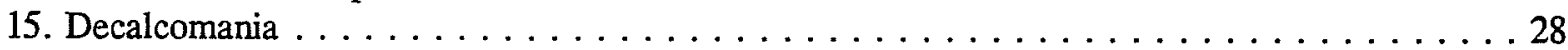

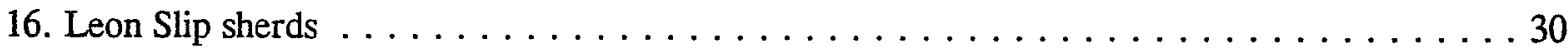

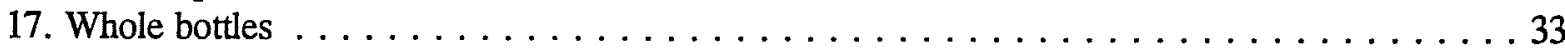

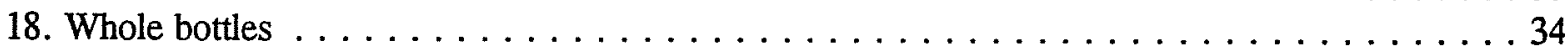

19. Carbide bicycle lamp . . . . . . . . . . . . . . . . . . . 37

\section{Tables}

1. SAHA Property Ownership History $\ldots \ldots \ldots \ldots \ldots \ldots \ldots \ldots \ldots \ldots$

2. Artifact Proveniences and Percentages . . . . . . . . . . . . . . . . 22

3. Ceramic Categories and Proveniences from the San Pedro Acequia (41BX337) . . . . . . . 24

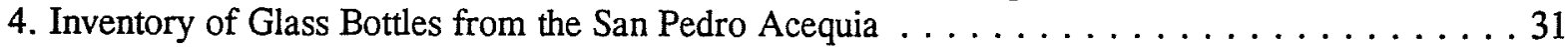

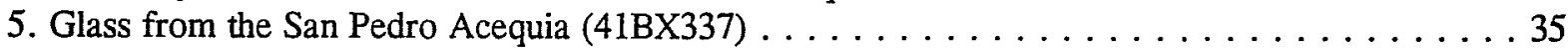

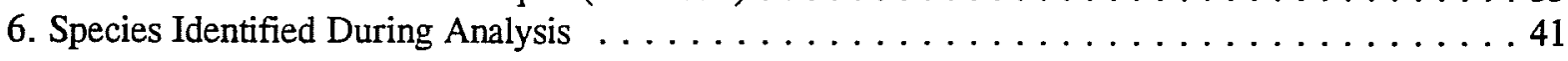




\section{Acknowledgments}

The authors wish to thank the co-principal investigator, Dr. C. Britt Bousman, for his advice and guidance; Oscar Cervantes of the San Antonio Housing Authority and Hilary Saunders of Beaty Saunders Architects for their help in initiating the project; and Christopher Kim, architect for the project, for his concern for the acequia. CAR staff members Andrew Scease, Ward Bramlett, Anthony Lyle, and Florencio Delgado provided competent fieldwork; and volunteers Darla Cox, Duke Smith, Tommy Tomesal, and Martha (Marty) Morrison contributed hearty and reliable support during excavations.

After the fieldwork, Robert R. Rector and Bruce Moses prepared the illustrations, and Curt Harrell and John Poindexter photographed the artifacts. Arna Gerritsen, René Muñoz, Flo Delgado, Troy Wilson, Cindy Tennis, and Jason Ruiz assisted with identification, processing, and cataloging of artifacts. Anne Fox graciously shared her knowledge of the artifacts and Barbara Meissner identified the fauna. Barbara Winsborough performed the diatom analysis. After the various parts of the report were assembled, editor Marcie Renner prepared the final publication. Finally, Dr. Robert J. Hard is recognized for his overall coordination and support of the project in his role as principal investigator. 


\section{Introduction}

David L. Nickels

This investigation of the San Pedro Acequia was motivated by expansion of the Central Office Building of the San Antonio Housing Authority (SAHA) at 818 South Flores, San Antonio, Texas (Figure 1). The proposed construction of a courtyard and addition of a new wing would possibly impact a buried acequia. SAHA architects and managers were concerned about protecting the acequia and met with the San Antonio Historic and Design Review Commission in May 1994. All parties agreed that a plan for mitigation was an appropriate solution toward documenting the historical acequia. In May 1994, SAHA contracted with the Center for Archaeological Research
(CAR) of The University of Texas at San Antonio to conduct archival research and archaeological testing to retrieve any information which might be available on the type of construction materials used for the acequia, as well as to determine its more precise location. CAR also proposed that analysis of the sediments could yield information regarding the nature of the acequia's water environment. Following the 1994 mitigation effort, the building was redesigned so that it bordered the western edge of the acequia. All parties then agreed that the architecture of the acequia within the project area had been sufficiently documented and no further work was warranted.

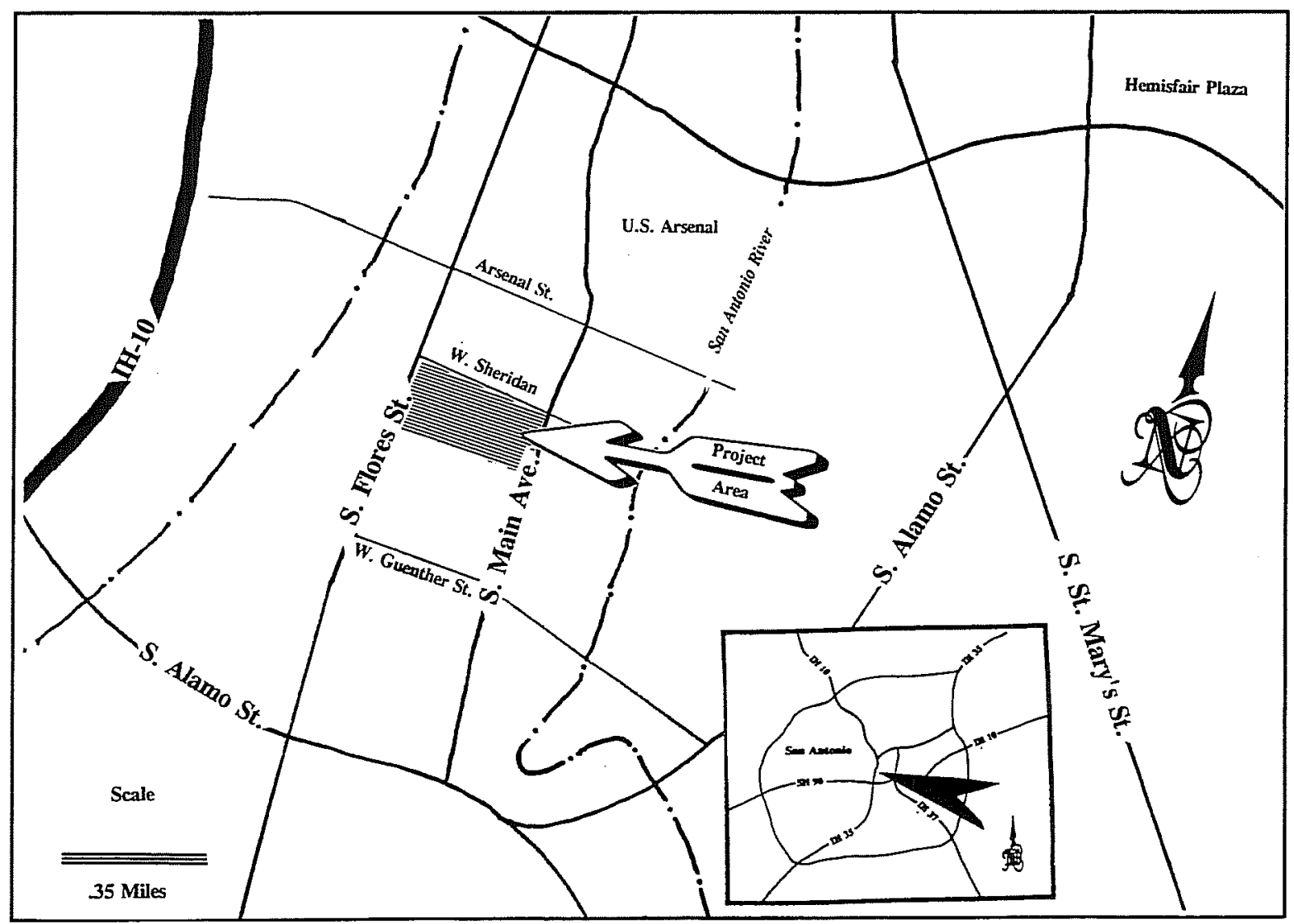

Figure 1. Location map. 


\section{History of the San Pedro Acequia I. Waynne Cox}

In 1724 Brigadier Pedro de Rivera y Villalon was dispatched by the viceroy of Spain to inspect and evaluate the frontier defenses of New Spain. The tour lasted until June 1728 and covered over 8,000 miles. One of the recommendations of Brigadier Rivera was that the frontier be settled with stable families, believing that "one permanent Spanish family would do more to hold the country than a hundred soldiers" (Chabot 1937:141).

On March 9, 1731, fifty-six Canary Islanders, consisting of sixteen families and four single men (de Alamazan 1731) arrived at the Presidio de Bexar to form the nucleus of the Villa of San Fernando de Bexar, the first civil settlement of Texas and what evolved into the city of San Antonio (Figure 2). Viceroy Casafuente ordered the newcomers be greeted and housed in the presidio until a villa was established a "gunshot's distance ... to the west of the presidio" (de Aviles 1731). The captain of the presidio, Juan Antonio Perez de Alamazan, delaying the laying out of the villa until after the planting season, selected "land subject to irrigation" as temporary fields for the Islanders.

On July 2, 1732, Captain Alamazan called the families together, having each bring two cart loads of stone and 10 stakes, to begin the survey of the town. The site selected by Casafuente, west of the presidio, was deemed unsuitable due to the difficulty of establishing irrigation. Therefore the captain altered the plan and located the new settlement east of the presidio. In keeping with the beliefs of the time, this required that the church be reoriented to face east. The final act in establishing the limits of the villa of San Fernando was the drawing of lots for farm plots by the Islanders. For farming, Alamazan selected a fertile area south of the villa between the San Antonio River and San Pedro Creek, down to their confluence. Each family was consigned a plot sufficient to plant their crops. The four single men were considered as two families (Alamazan 1731).

The two streams were so deeply entrenched in this area that irrigation was difficult. Therefore, an acequia was envisioned, leading from San Pedro Springs, then southward between the water courses and returning to the river just prior to the confluence (Figure 2). The design presented two distinct advantages: first, it could service the presidio, the villa, and the Islanders' fields; second, by following the high ground between the two water courses, it could irrigate lands on both sides, in contrast to the other acequias which only watered the lands toward the river. When the task was begun and completed is not recorded, but it is logical to assume that construction was initiated soon after assignment of the land. On January 11,1734 , by order of the viceroy, lands were re-surveyed and official title was granted to the Islanders. Excess land was also granted to eight other citizens of the villa (Leal, J. O. [translator], "Division of the Lands of the Canary Islanders in San Antonio"; typescript copy dated 1986, in the Bexar County Archives, Bexar County Courthouse, San Antonio, Texas). In all probability, the acequia was in operation by January 1734 .

With the completion of the San Pedro Acequia, the entire basin between the creek and the river could now be irrigated from the area of the springs at the head of San Pedro Creek to its confluence with the San Antonio River. The channel was some $6.4 \mathrm{~km}$ in length and watered approximately 400 acres below the villa, the new lands of the Islanders and other citizens. The acequia served irrigation purposes for the remainder of the eighteenth century through the early twentieth century.

The transfer of the lands from Spain to Mexico had little impact on their usage. The old Spanish law of irrigation continued, the amount of 


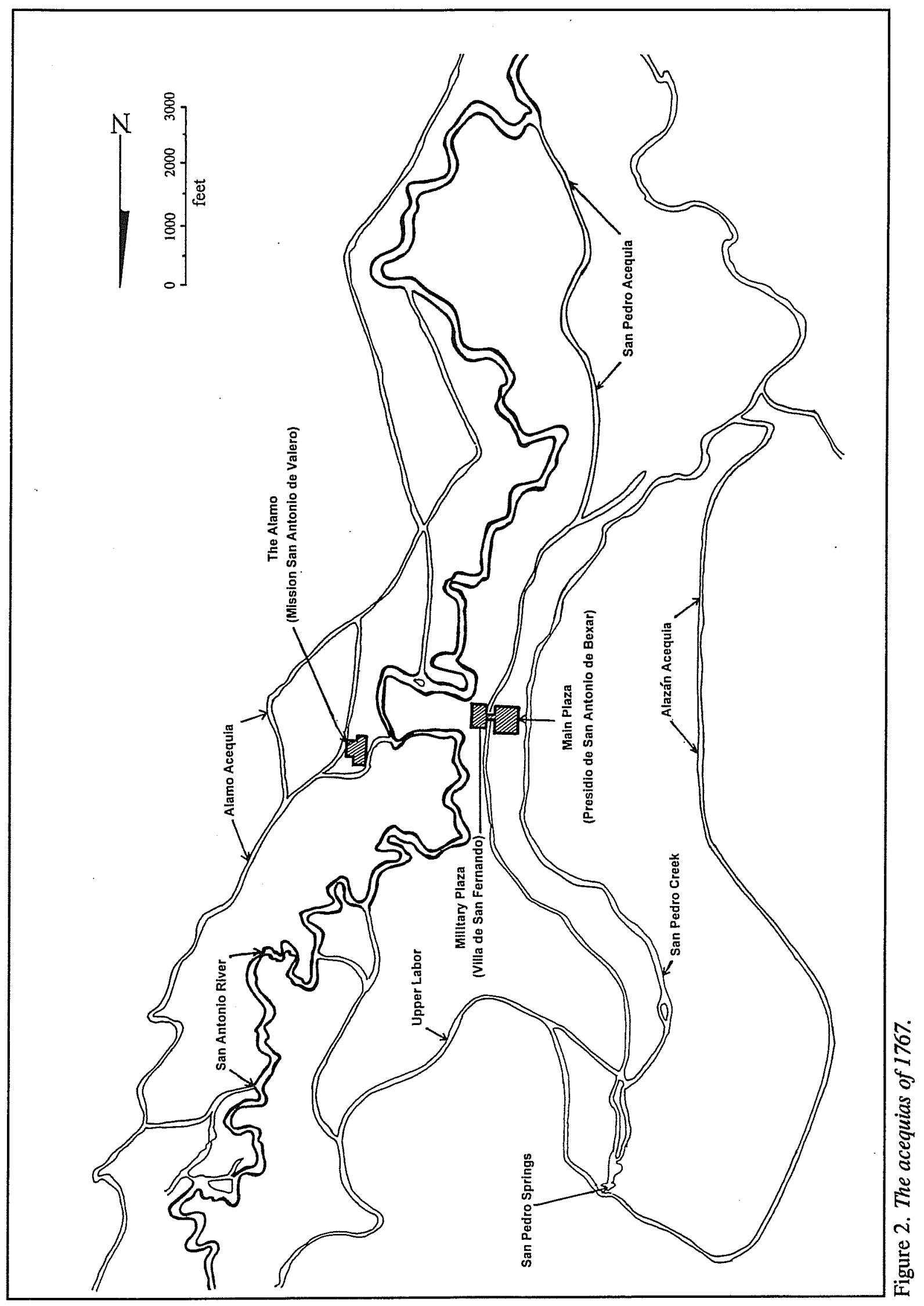


allowable water was regulated by the irrigation rights granted within the deed. Initially, with the coming of the Republic of Texas, the land remained in agriculture with the same laws and regulations respected by the new government. However, speculators soon began to exploit the only resource the new Republic possessed: land. By an act of the Congress of the Republic of Texas on December 20,1836, Bexar County was formed. The county's lands extended from the mouth of the Rio Grande to the Texas Panhandle, and as far west as El Paso. Speculators flocked to San Antonio-the seat of Bexar County-to survey and register their claims, boosting the population of the city.

With the expanding population came increased utilization of the acequia system. In January 1840 , the city council found it necessary to issue a lengthy and severe ordinance concerning the upkeep of the acequias. The ordinance observed that the main ditch of the San Pedro acequia from San Pedro Springs "not having been cleaned out for many years" would require a great expenditure of effort, but all landowners were responsible to clear the ditch and open it to its original depth (City Council Minutes [CCM], Office of the City Secretary, City Hall, San Antonio, Texas, A:37). Those failing to properly clear their share of the acequia would be required to pay 50 cents for each vara $(.85 \mathrm{~m})$ cleared by the municipality. Those refusing to pay the assessed cost after 10 days would forfeit "his or her water privileges for the space of twelve months to the use of the corporation" (CCM, A:37). They further decreed that any person or persons placing an obstruction to impede or retard the "free passage of the water" should be fined $\$ 5.00$ plus costs to remove the obstruction for the first offense, and $\$ 20.00$ plus costs for every offense thereafter. Those unable or unwilling to pay "shall be sentenced to work on the Public Works of the city" at 50 cents per day (CCM, A:37). The ordinance also provided for the creation of the position of ditch commissioner (CCM, A:37); Francisco Ximenes was selected to fill the position at the following session.
By the latter half of the nineteenth century, the acequia system was being used less for irrigation and more for drainage. In July 1883 , a special committee was assigned to evaluate the need for the irrigation ditches versus their cost effectiveness. Alderman Lockwood delivered the report to council and found "the city expending, for 411 persons, not less than $\$ 4000$ per year, including salaries of ditch commissioners, repairing of bridges, cleaning of ditches \&c. As near as we could ascertain, 29 persons out of the 411 are engaged in the business of raising vegetables for sale to the public" (San Antonio Express [SAE], 21 July 1883). However, the committee agreed that some system of draining excess water from the city was necessary, and that the acequias did to some extent fulfill that function. But they also felt that a sewage system designed strictly for that purpose might be more effective, especially on the east side of the river. "This drain would relieve the ditch of all the surplus water that flows into it during the prevalence of heavy rains from the hills east of the Sunset railroad depot" ( $S A E, 21$ July 1883).

At the same meeting Alderman Belknap brought to the council's attention "our city is no longer a whistling station or a country village, but is fast taking the position of a populous city" ( $S A E, 21$ July 1883). He therefore proposed a special board be appointed to submit a plan of public improvements throughout the city, "said estimates not to exceed in amount $\$ 250,000$ " to be financed with public bonds ( $S A E, 21$ July 1883). Among the recommendations within the proposal was the construction of a new sewage system. The local press responded that "the question of sewage in a populous city is of all questions the most vital. The city becomes famous as a health resort or it acquires a fame for epidemics and loathsome diseases according to its successful or unsuccessful system of sewerage" ( $S A E, 21$ July 1883). At the next session of council the city physician requested "that the Alamo ditch from its intersection with the Madre ditch to Goliad Street be condemned, as well as all branches, as channels of infection and annoyance" (SAE, 22 August 1883). 
At the council meeting of September 4, 1884, the ditch commissioner reported that filth was being conducted to the Madre ditch "from the U.S. hospital, Major Kampmann residence and the Menger Hotel." To that, Alderman Arthur I. Lockwood retorted that he "had no idea there was no one who did not know it was impossible to keep the water in the ditches so it would be fit to drink. Two-thirds of the diseases in this city come from that source" ( $S A E, 5$ September 1883). At the next meeting Alderman Lockwood had the following resolution presented to council.

Whereas, it is well known to every member of this council, and to every intelligent citizen of this city, that the water of the San Antonio river and San Pedro creek, and the Alamo or Madre, and Alazan and San Pedro ditches, and all their branches, after entering the city limits, are unfit for drinking or domestic purposes. And whereas, it is utterly impossible to keep the water of said streams and ditches, pure and undefiled in their devious courses through a city of 30,000 people, living along the banks of said streams and ditches. And whereas, it is a recognized and established fact, that the San Antonio river and the San Pedro creek, are the natural drains of this valley. Therefore be it resolved, that the San Antonio river and the San Pedro creek, the Alamo or Madre, Alazan and San Pedro ditches, with all their various branches, are hereby declared to be a part of the system of drainage, and the people are hereby notified not to use said water for any other purpose other than irrigation [CCM, E:520-523].

In 1890, with respect to the acequias of the city, the mayor was moved to comment, "there is little to be said on this subject, except that as now used they are an expensive luxury" ( $S A E$, 30 April 1890). He did not, however, recommend that they be filled, "for at not a very distant day the ditches on the east and west side of the city may be used advantageously in solving the sewerage propositions" ( $S A E, 30$ April 1890). He further noted that the cost of maintaining the west side was far in excess of the east side, but he credited this to the fact that the western ditches had not been properly cleaned "for a decade" (CCM, I:17).

At the first meeting of a new administration of 1899, Mayor Hicks presented his address stating the direction his administration would take. He stressed several areas that he considered critical to efficient government; among these was the operation of the sewer system which must "be carefully managed under the supervision of a skilled and competent inspector, and that our laws in regard to its operation be so framed as to afford the utmost safety to our citizens" ( $S A E$, 28 February 1899). An area that he felt needed drastic changes was in the sector of public health. He proposed the creation of a new department of street cleaning and sanitation

which shall control the collection and disposition of garbage and refuse, the sweeping and sprinkling of the streets, and the cleaning of the various ditches and the river, and that the office of ditch commissioner be abolished. This will relieve the street commissioner of a portion of his duties and enable both departments to be carried on with greater efficiency and less expense [SAE, 28 February 1899].

At the March council meeting, August Santleban, new superintendent of street cleaning and sanitation, reported upon the condition of San Pedro Ditch and Creek.

I find the Flores street ditch from San Pedro Springs to Johnson street not cleaned this year; from Johnson street to Main ditch and branch running across South Flores street was cleaned by the former ditch commissioner; I also find the various water gates in great need of repair. Also on Herff and Nacogdoches streets I find that the ditch is leaking and needs repairing. I also find San Pedro creek from San Pedro Spring to South Flores street crossing in a filthy condition and needs immediate attention [SAE, 14 March 1899]. 
In December 1909, action was taken to see that the venerable waterway was to be dealt the fate of the other acequias that had once watered the city. "The picturesque old North Flores Street ditch which irrigated the gardens of the earliest settlers from Spain and France who helped win San Antonio from sterility and the Indians must go" (SAE, 3 December 1909). The Board of Health noted that it no longer served its purpose and served only as a "menace to the public health" and ordered it closed ( $S A E, 3$ December 1909). In fact, the council was beset by citizen petitions requesting both that the waterway be closed and remain open. Finally, in September 1912, the council enacted ordinance JV-10 stating: "that said San Pedro Ditch be, and the same is hereby closed" (CCM, V:39).

With this action, the last of the downtown acequias was officially closed. Although the acequias lie buried beneath the city streets, their impact can still be seen by the street patterns and property lines that trace the path of the old waterways through the downtown area. Some small fragments are still used as a portion of the storm water drainage system within the downtown area. 


\section{Acequia Construction}

\section{David L. Nickels}

The original Spanish acequias were merely unlined earthen ditches with dams, gates, and other flood-control devices constructed of stone or timber. By the time of the Anglo-American period, the primary construction material was the abundant limestone of the area, cut and dressed into blocks. On February 2, 1852, city council adopted a resolution by Alderman Lockhart which constituted the first major revision to the system since its construction some 120 years earlier.

Resolved that the mayor be and is hereby authorized to receive proposals for constructing a ditch across Main Plaza in line of the present dilapidated one of the following dimensions, three feet wide at the bottom and four feet wide at the top, solid masonry of stone laid in sand and lime. Wall eighteen inches thick to be paved at the bottom with flat stone. Excavated and completed, the surplus dirt to be deposited in the old or present ditch under the supervision of the mayor and Improvements Committee [CCM, B:158-160].

The ordinance further called for sealed bids to be submitted by the following council meeting, and that stone and lime to meet the specifications be displayed at the mayor's office for the guidance of the contractors. This is the first instance of the lining that would be undertaken on the various channels throughout the downtown area (CCM, B:158-160). Stone lining of the acequia later occurred as larger lots were subdivided and portions of the acequia were moved to conform to property lines. This material served as the least expensive, most durable material available, until the advent of rail transportation in 1877 . With the arrival of the Galveston, Harrisburg and San Antonio Railroad (GH\&SA RR), new and cost effective materials-such as brick and milled lumber from the factories and mills of East Texas-became available.
As early as 1880 , the city began to have problems with the newly completed stone-lined Alazan Ditch. The deep cut near the intersections of North Flores and Cypress streets and Fredericksburg Road (Five Points) was overflowing with each heavy rain. The city engineer proposed to raise the channel with a wooden extension. He proposed a "box two feet square of one and a half inch lumber, the top covering to be made as to leave a 'man hole', six feet long, every twenty feet, to expedite the cleaning of the same" (SAE, 22 December $1880)$. He estimated that this would require 12,800 board feet of lumber at a cost of $\$ 584$.

On December 3, 1881, the city engineer, Charles P. Smith, and the ditch commissioner, B. Wilkins, jointly reported the results of their inspection of the "Upper Labor, Alazan, and San Pedro Ditches." Their report included among the recommendations that a break "be revetted with 30 running feet of plank, 4 feet high, secured to cedar piles 3 feet apart" (City Survey Book [CSB], Bexar County Archives, Bexar County Courthouse, San Antonio, Texas, 2:402-403). The following week, they detailed work that was required for the Valley Ditch, on the east side of the river, recommending "the construction of a wooden culvert . . . its sides and top to be of good heavy $1 \frac{1 / 2}{2}$ inch . . . lumber-supported outside by cedar pickets placed every 3 feet-which pickets shall have every alternate pair kept in place by scantling $2 "$ x 4 " and 4 feet long placed crosswise" (CSB, 2:410). Wood lining renovation was the last technique used before the acequias were ordered closed in 1912. 


\section{San Antonio Housing Authority Property History I. Waynne Cox}

In the 260 years since the Canary Islanders first drew lots for the land in 1732, the SAHA property changed ownership numerous times (Table 1). During the initial division of the lands below the villa, the twelfth lot drawn was assigned to Juan Delgado. He was born in 1711 on Lancerote, the northeasternmost island of the Canary Group, and on the journey to Texas married Catarina Leal, the daughter of the leader of the group, Juan Leal Goraz (Buck 1980:39; Chabot 1937:171).

Upon the death of Delgado in 1745, the property passed to his youngest son, Juan Amador Delgado. Upon Juan's death in 1799, the property passed to his heir, José Delgado, and then to José's heirs, Nicolas, Casiana, and Amador in 1837 (Chabot 1937:172-173).

On October 3, 1848, the Delgado heirs conveyed the property to Lecomte de Watine for $\$ 100$ (Bexar County Deed Records [BCDR], Bexar County Courthouse, San Antonio, Texas, G1:439). In March 1855, the property was purchased by Jesus and Catarina de la Garza, and five months later conveyed to John Stewart McDonald (BCDR, G2:136, 01:462).

McDonald, who arrived in San Antonio in 1838, served as mayor in 1851 and, the following year, joined J. H. Lyons as co-publisher of the Western Texan and assisted Samuel Maverick in surveying several of the western forts. In 1856, while engaging in a heated political discussion, McDonald and Dr. James M. Devine, then mayor of the city, entered into a scuffle, a shot was fired, and McDonald was fatally wounded (Cox 1991:2-5). His estate passed to his wife, Clintonia, who later married Robert S. Sibert (Marriage Records, Vital Statistics, Office of the County Clerk, Bexar County Courthouse, San Antonio, Texas, D2:386).
In 1870 Clintonia and Robert Sibert sold six acres of the tract to entrepreneurs H. B. Adams and E. D. L. Wicks for $\$ 3,000$. That portion consisted of property between Sheridan and Johnson streets and extended from South Flores Street to the San Antonio River (BCDR, V2:339). Adams and Wicks then conveyed the property to $M$. Goldfrank, who in turn sold the property to Jon T. Medclafe, who conveyed the tract to Joseph S. Lockwood. The latter, then president of the Lockwood and Kampmann Bank, sold the entire tract to R. M. Thomson for $\$ 5,000$ in March 1882 (BCDR, 23:28). In 1886 Thomson had the property subdivided into house lots and donated land to the city for the establishment of Johnson Street (BCDR, 51:221).

Thomson sold one of his first newly divided lots to August Pelleton for $\$ 800$ in April 1887 (BCDR, 54:228). Pelleton, a gardener at the U.S. Arsenal just to the north on Flores Street, had a home constructed facing on Johnson Street in late 1888 or early 1889 (City Directory [CD] 1887-1888, 1889-1890). Antonio G. Castanola had his home constructed at 824 South Flores Street in 1890. Castanola, in partnership with his mother Margarita, conducted a wholesale and retail grocery business on Acequia (later Main) Street (CD 1891). The following year Charles Graebner, a salesman and soon-to-be vicepresident of the Dueuler Manufacturing Company, established his residence at 818 South Flores Street (CD 1892-1893). These homes occupied the site until the 1960 s when the property was purchased and cleared by the United States government for a post office. After another site was selected for that purpose, the property was made available to the city of San Antonio (Cox 1991:6). The city held the land, awaiting a suitable use. The property was later transferred to SAHA, an independent entity within the city government, and the new administrative building was constructed in 1984 . 
Table 1. SAHA Property Ownership History

\begin{tabular}{|c|c|c|}
\hline Owner & Transaction & Date \\
\hline Juan Delgado & drew lot & 1732 \\
\hline Juan Amador Delgado & inherited & 1745 \\
\hline José Delgado & inherited & 1799 \\
\hline Nicolas, Casiana, and Amador Delgado & inherited & 1837 \\
\hline Lecomte de Watine & purchased for $\$ 100$ & October 1848 \\
\hline Jesus and Catarina de la Garza & purchased & March 1855 \\
\hline John Stewart McDonald & purchased & August 1855 \\
\hline $\begin{array}{l}\text { Clintonia McDonald } \\
\text { [then married to Robert Sibert, joint ownership] }\end{array}$ & inherited & 1856 \\
\hline H. B. Adams and E. D. L. Wicks & $\begin{array}{l}\text { purchased 6-acre tract } \\
\text { for } \$ 3,000\end{array}$ & 1870 \\
\hline M. Goldfrank & purchased & June 1874 \\
\hline Jon T. Medclafe & purchased & March 1876 \\
\hline J. S. Lockwood & purchased & March 1882 \\
\hline R. M. Thomson & $\begin{array}{l}\text { purchased for } \$ 5,000 \text {; } \\
\text { subdivided into lots }\end{array}$ & $\begin{array}{l}\text { March 1882; } \\
1886\end{array}$ \\
\hline August Pelleton & $\begin{array}{l}\text { purchased one lot for } \$ 800 \text {; } \\
\text { built home }\end{array}$ & $\begin{array}{l}\text { April } 1887 \\
1888 \text { or } 1889\end{array}$ \\
\hline Antonio G. Castanola & $\begin{array}{l}\text { purchased one lot; } \\
\text { built home }\end{array}$ & $\begin{array}{l}\text { November 1889; } \\
1890\end{array}$ \\
\hline Charles Graebner & $\begin{array}{l}\text { purchased one lot; } \\
\text { built home }\end{array}$ & $\begin{array}{l}\text { February 1886; } \\
1891\end{array}$ \\
\hline U.S. government (for post office) & purchased & 1960 s \\
\hline City of San Antonio & transfer & 1968 \\
\hline
\end{tabular}




\section{Previous Archaeological Investigations David L. Nickels}

The meandering course of the San Pedro Acequia (41BX337) has been investigated in fragmented sections by archaeologists over the past 18 years. In 1977 the acequia was uncovered by CAR on the grounds of the old U.S. Arsenal, two city blocks north of the SAHA project area; there the acequia walls were $150 \mathrm{~cm}$ apart and constructed of cut limestone blocks up to $60 \mathrm{~cm}$ thick (Fox 1978:2-11). Trenching operations monitored by CAR in July 1985 revealed cut-limestone construction of the acequia along Duffield Street, three kilometers northwest of the project area (Cox 1986:4-6). Excavations by CAR in 1978 revealed cut-stone lining in the acequia just south of Main Plaza on the site of the new Bexar County Justice Center (Fox et al. 1989:25-28). That section of the acequia is one kilometer north of the SAHA project area. The acequia was again uncovered and subsequently documented by CAR in 1994, beneath Treviño Street at its intersection with Main Plaza; once again, the acequia at this point was lined with cut limestone (Cox 1995:5-6).

By far the most concentrated investigations previously conducted on 41BX337 (Figure 3) were in the immediate area of SAHA in June and November 1979 (Frkuska 1981; Valdez and Eaton 1979). Prior to the construction of a proposed new post office on the South Flores Street property that is now owned by SAHA, CAR conducted trenching operations to determine if the San Pedro Acequia ran through the property. Insurance maps from the early 1900 s indicate the approximate course of the acequia. Absent, however, is any indication of the type of construction material used on the acequia this far south of Main Plaza. In June, 13 trenches were systematically dug across the property in an attempt to crosscut the acequia. Three of the trenches $(7,11$, and 13) cut through parts of the acequia that were simply dug into the Houston Black Clay and caliche, with no evidence of stone or wood lining. However, two trenches (11 and 12) revealed a lining of cut limestone and sandy lime mortar. Thus, archaeological research confirmed what the archives could not: that stone lining was used this far south of Main Plaza.

In November 1979, CAR returned to the site to further identify and more accurately map the course of the acequia (Frkuska 1981). An additional 12 trenches were dug; stone lining was discovered in five (A, E, F, Q, and $R$ ) and the unlined ditch discovered in six. In one of the trenches (B) a cedar plank and a post were found, and in another trench (D) a single plank and post hole were found. At the time it was believed that the wood represented some sort of retaining wall, but researchers were unable to determine the exact construction methods or extent of the retainers. The artifacts recovered from the stone-lined sections of the ditch were early twentieth century (Frkuska 1981:7-47). 


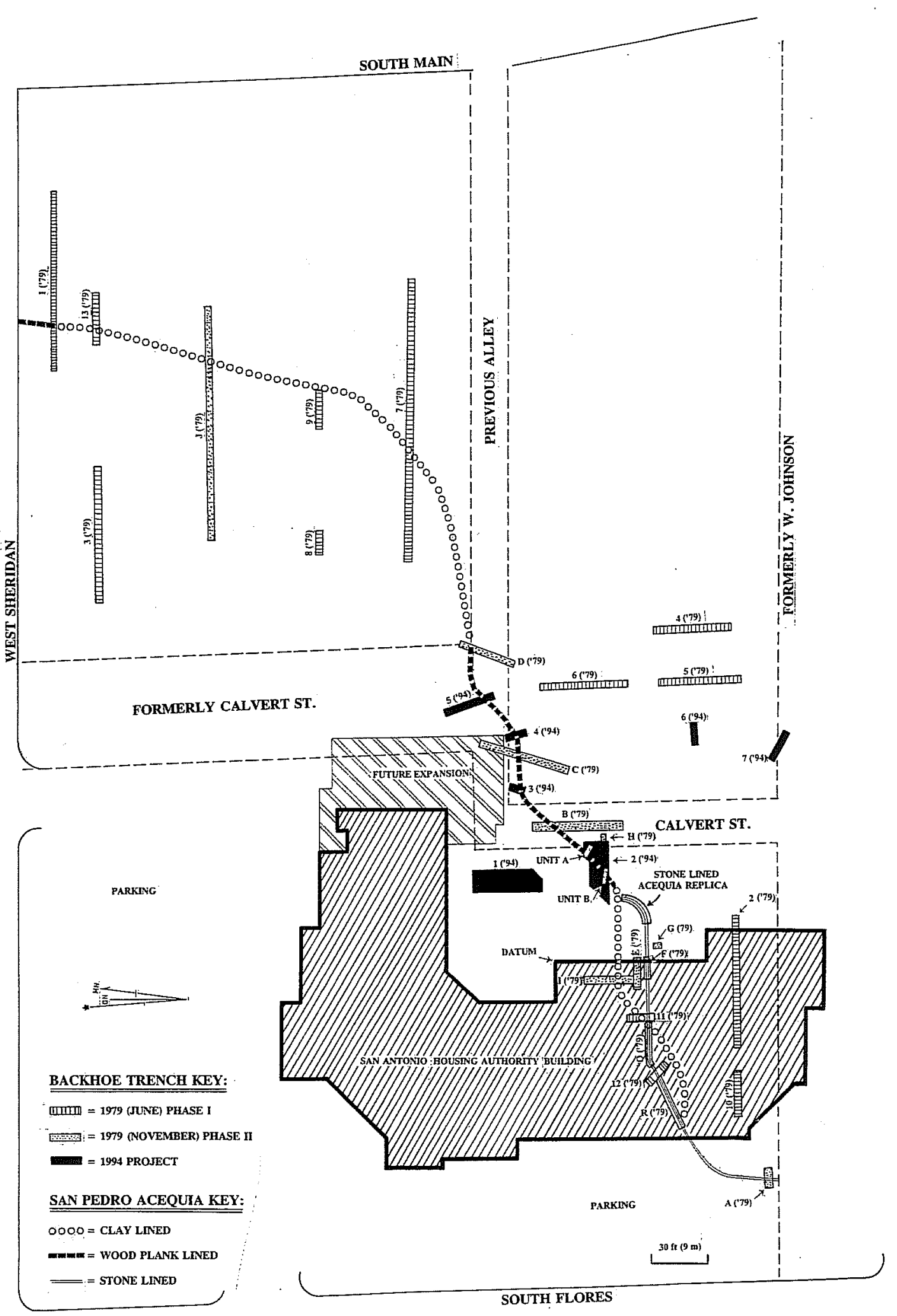

Figure 3. Archaeological investigations on the SAHA property and route of the San Pedro Acequia. 


\section{Methods and Results \\ David L. Nickels}

\section{Field Methods}

The primary purpose of the current project was to identify the route and architecture of the acequia in the area to be impacted by future building expansion. Deeply buried pylons within the footprint could destroy portions of the historically designated San Pedro Acequia (Figure 3). Excavations conducted by CAR in 1979 enabled staff archaeologists to project the suspected route of the acequia (Frkuska 1981). A replicated portion of the stone lining had been constructed for public display within the enclosed courtyard. The projected route of the acequia was to have taken it approximately $15.2 \mathrm{~m}$ north from the stone-lined replica before turning 90 degrees to the east, and then exiting the courtyard area (Frkuska 1981:10,19). A datum was established at a northeast corner of the administration building (Figure 3) for the 1994 project.

The strategy was to identify the projected course of the acequia on the grassy surface, and then to confirm its existence with subsurface probes. Previous excavations had revealed that the top of the acequia was about $30 \mathrm{~cm}$ below the modern surface (Frkuska 1981:14). Methods of probing and excavation included Gradall and backhoe trenching, shovel testing, and hand excavation using trowels and brushes. Each trench and excavation unit is described in detail below.

In July 1994, a Gradall with a 1.52-m bucket was used to remove the sediment above the acequia. Based on Frkuska's 1981 projection, Trench 1 was dug $10.6 \mathrm{~m}$ north of the stone replica (Figure 3). Expectations were that the area uncovered by Gradall operations at this point would reveal not only the north extension of stone lining, but also the 90 degree turn toward the east. No evidence of the acequia-either lined or unlined-was found in Trench 1. Therefore a second trench (2), was begun two meters north of the stone-lined replica
(Figure 3) and the acequia was discovered. Gradall operations stopped when the top of the acequia was identified.

Six shovel tests were placed within Trench 2, crosscutting the outline of the acequia. Shovel testing has proven effective in discovering artifacts and features in and around mission-era structures (Hard et al. 1995:20-41). Shovel testing was used to validate soil differences, stratigraphy, and artifact density in and outside the acequia channel. The shovel testing technique proved to be an effective method for locating an acequia in locations either inaccessible or unsuited for heavy machine excavations.

Two hand-excavation units, $0.5 \times 2 \mathrm{~m}$, were placed within Trench 2 (Figure 4, Units $A$ and B), exposing the acequia profile from top to bottom. Projecting the course of the acequia as uncovered in Trench 2, three more trenches (3, 4 , and 5) were placed to the northeast using a backhoe with a $66-\mathrm{cm}$ bucket (Figure 3 ). The acequia was found in all three trenches. Two additional trenches ( 6 and 7) were placed to the south of trenches 4 and 5 . Although the acequia was not expected to be found in this area (previous investigations had confirmed its course several meters to the west), these last two trenches were placed to explore for other types of historical features. Sanborn Insurance Company maps (San Antonio Public Library, San Antonio, Texas) and Augustus Koch's Bird's Eye View of the City of San Antonio for 1873 (copy on file in the collections of the San Antonio Museum Association, San Antonio, Texas) indicated residential structures existed in this area in the early 1900s; however, no other archival data was available to determine the types of activities at this location prior to its development in the late 1880 s.

The archaeological team drew plans and profiles of all trenches, shovel tests, and unit excavations. All drawings are on file at the CAR laboratory. 


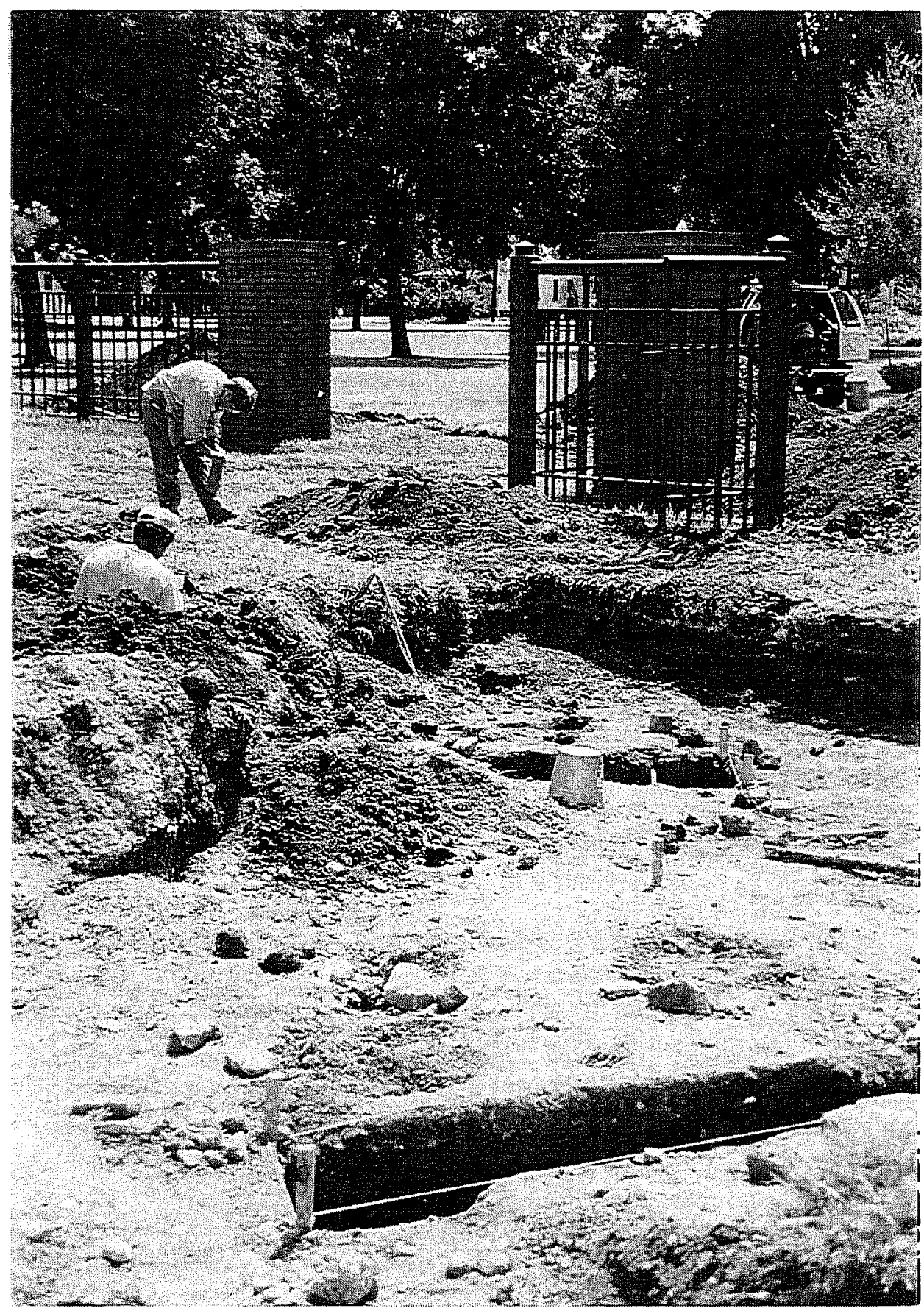

Figure 4. Hand-excavation Units $A$ and B, within Trench 2, July 1994.

\section{Results}

\section{Trench 1}

Trench 1 was $2.7 \mathrm{~m}$ wide $\times 10.6 \mathrm{~m}$ long, and ran from south to north. Its southwest corner was $63.6 \mathrm{~m}$ from east South Flores Street and $84.5 \mathrm{~m}$ south of West Sheridan Street. Previous investigations (Frkuska 1981) suggested that the stone lining of the acequia would be exposed approximately $30 \mathrm{~cm}$ beneath the modern surface. These investigations indicated that the stone-lined acequia would run north, then turn abruptly to the east within the trench area. Using a Gradall, the sediments were scraped off a few 
centimeters at a time to a depth of $76 \mathrm{~cm}$. No trace of the acequia was encountered. The sediments appeared highly disturbed, with inclusions of orange, gray, and white gravels, and metal and plastic pipes embedded within the black clay and brown sandy loam. Archaeologists carefully monitored the trenching and backdirt for cultural material. This trench was within the courtyard area of the current SAHA administration building; this area was evidently disturbed during construction. The profile showed several layers of gravel fill. In view of the negative results within Trench 1 , the Gradall was relocated to the south.

\section{Trench 2}

Trench 2 was $6.1 \mathrm{~m}$ wide $\times 10.4 \mathrm{~m}$ long, and ran from east to west. Its southwest corner is $61.6 \mathrm{~m}$ east of South Flores Street and $95.4 \mathrm{~m}$ south of West Sheridan Street. Trench 2 was placed in a direct line between Trenches $\mathrm{C}$ and F. The latter were dug in 1979 , at which time the stone lining was confirmed $10 \mathrm{~m}$ to the southwest in Trench $F$ and cut limestone fragments were observed $27.4 \mathrm{~m}$ to the northeast in Trench C (Frkuska 1981:15-17, 19-20).

The Gradall scraped off approximately eight centimeters of sediment before encountering a brown loamy clay. Archaeologists carefully monitored the trenching operations and backdirt for cultural material. The top of the acequia was encountered at $50 \mathrm{~cm}$ below the surface (bs). Its outline was represented by two cedar planks (acequia walls) parallel to each other, rusted metal chunks, broken glass, and charcoal within a 2.4-m-wide strip of gray ashy clay that had accumulated both inside and outside the cedar planks. Trench 2 exposed 6.7 lineal meters of the gray clay strip extending to the northeast on a compass bearing of 47 degrees, allowing for a visual perspective on the acequia's projected course. In the southwest corner of Trench 2, fragmented concrete slabs approximately $15 \mathrm{~cm}$ thick x $46 \mathrm{~cm}$ long were uncovered 15 to $30 \mathrm{~cm}$ bs. A concrete cap which appeared to cover the stone-lined acequia had been encountered in Trench K in 1979 (Frkuska 1981:22-23). The slabs unearthed in Trench 2 do not correlate with those uncovered in 1979 , approximately $39.6 \mathrm{~m}$ distant. The concrete slabs in Trench 2 are most likely the remains of outbuildings removed in the 1960s.

\section{Trench 3}

The southwest corner of Trench 3 was $79.9 \mathrm{~m}$ east of South Flores Street and $81.4 \mathrm{~m}$ south of West Sheridan Street. This trench was three meters long and $66 \mathrm{~cm}$ wide (Figure 5), on a magnetic north bearing of 44 degrees. Figure 3

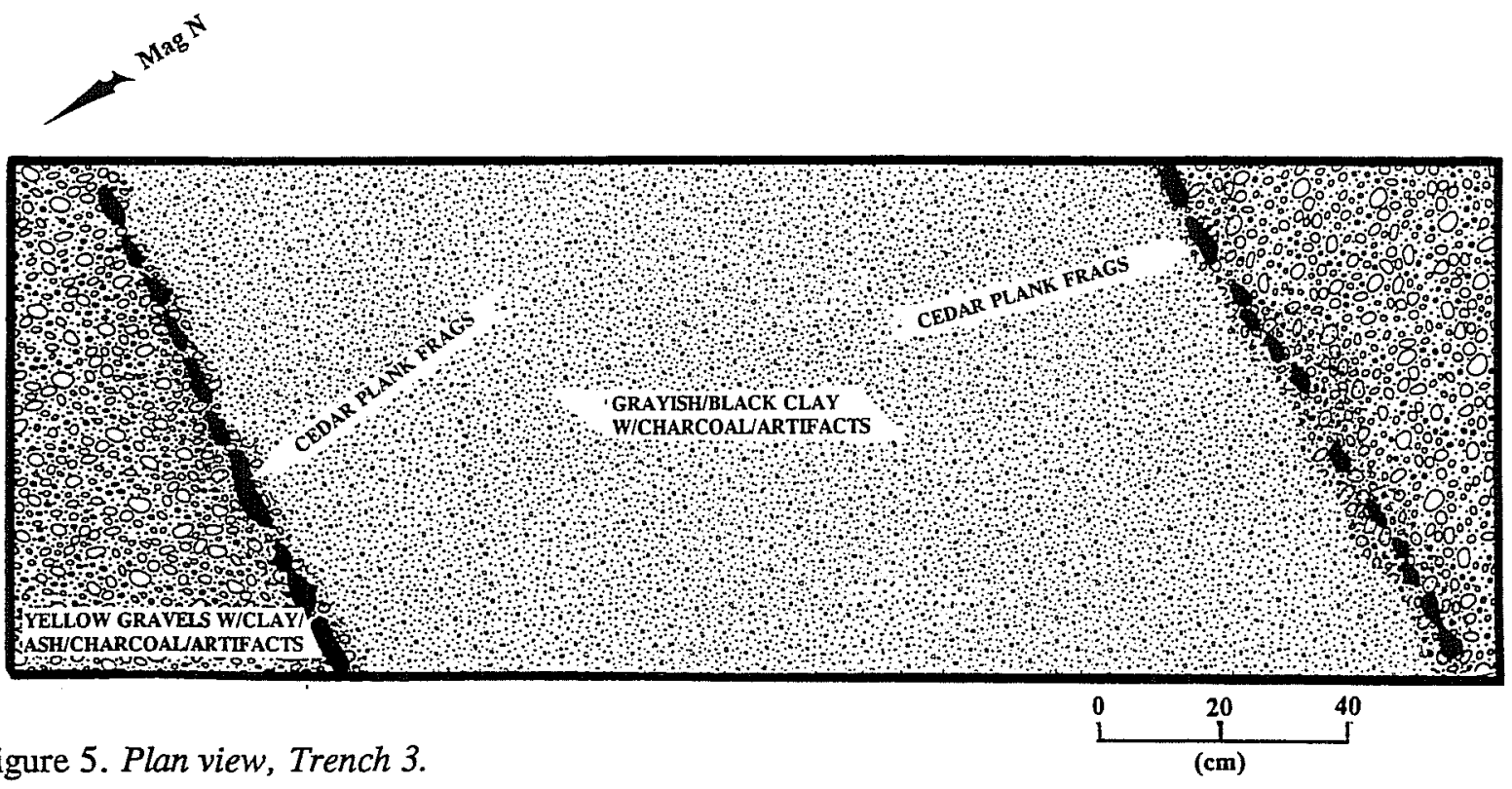


shows a 1.9-m section of the trench where two acequia cedar planks running parallel to each other at a bearing of 95 degrees were encountered at $50 \mathrm{~cm}$ bs. The distance between the planks (acequia's interior) was $144 \mathrm{~cm}$. The planks were badly deteriorated, yet some fragments were up to four centimeters wide. Hand excavation further exposed the planks to $56 \mathrm{~cm}$ bs (Figure 5). No evidence of cedar posts was found. Having determined the course and construction materials, no further excavation was deemed necessary. Ash, charcoal, and early twentieth-century trash occurred in the trench between $45-50 \mathrm{~cm}$ bs over the course of the acequia. The sediment at the same level likewise turned to an ashy gray. Trash was heavily concentrated within the walls of the acequia, while gravels were concentrated outside the walls.

\section{Trench 4}

The southwest corner of Trench 4 was $89.3 \mathrm{~m}$ east of South Flores Street and $82.3 \mathrm{~m}$ south of West Sheridan Street. This trench was $4.4 \mathrm{~m}$ long and $66 \mathrm{~cm}$ wide, on a magnetic north bearing of 16 degrees. Ashy gray-black sediment was encountered between $45-50 \mathrm{~cm}$ bs. The top of a cedar post appeared at $50 \mathrm{~cm}$. This trench was taken down by backhoe to $90 \mathrm{~cm}$, exposing caliche at $70-80 \mathrm{~cm}$ (Figure 6). Due to severe deterioration and sediment mixing, the depth at which the post was initially set into the caliche could not be determined. The stratigraphic infilling indicated that this should be the post supporting the west wall. The only other evidence indicating a possible wood-lined eastern wall was a wood plank, lying at a 65 degree angle and contiguous with the slope of the infill. Based on the stratigraphy and the plank, the

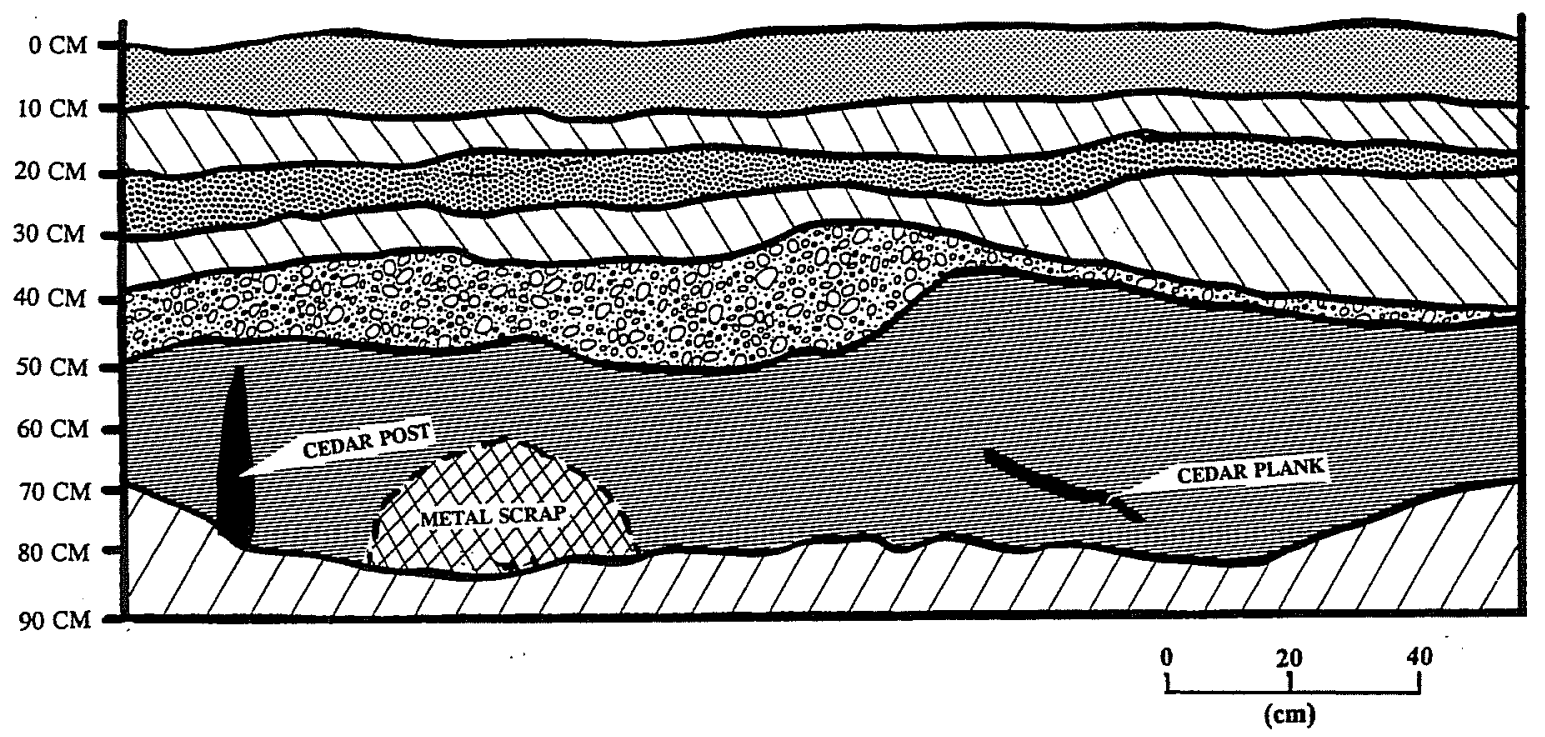

BLACK CLAYEY LOAM

LID CALICHE

YELLOW CALICHE FILL
BROWN CLAYEY LOAM

GRAYISH BLACK CLAY

DOי YELLOW GRAVELS

Figure 6. West wall profile, Trench 4. 
acequia was estimated to be $144 \mathrm{~cm}$ wide and its bearing was estimated at 95 degrees from this point. The fill both inside and outside the acequia contained sparse numbers of glass, bone, and ceramics, as well as a concentration of round nails and other metal scrap. It should be noted that a separate cedar post was found in the east end of the trench, $3.35 \mathrm{~m}$ east of the post described above. Its distance from the acequia and lack of evidence for stratigraphic infilling suggest it is a probable fence post.

\section{Trench 5}

The southwest corner of Trench 5 was $95.4 \mathrm{~m}$ east of South Flores Street and $76.8 \mathrm{~m}$ south of West Sheridan Street. This trench was $8.2 \mathrm{~m}$ long and $66 \mathrm{~cm}$ wide, on a magnetic north bearing of 341 degrees (Figure 3). The top of a cedar post was exposed on the north side at 60 $\mathrm{cm}$ bs, and two cedar planks at $62 \mathrm{~cm}$ (Figure 7). The gray-black clay was at the same level as the top of the post and planks, and extended in depth inside the acequia walls to $75 \mathrm{~cm}$. Underlying
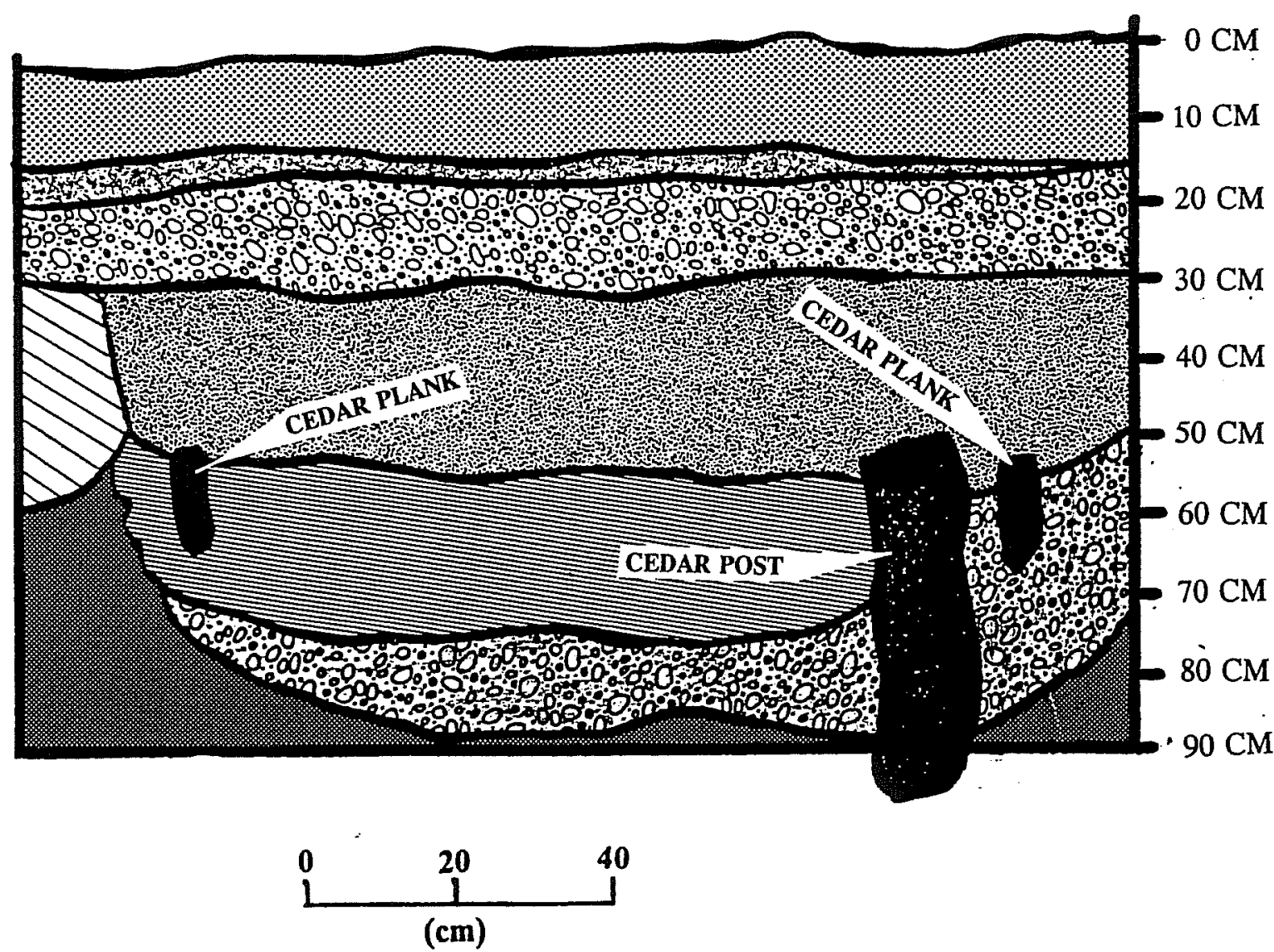

BROWN CLAYEY LOAM

LIGHT BROWN CLAYEY LOAM

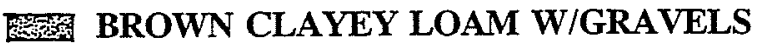

GRAYISH BLACK CLAY

POPG YELOW GRAVELS

BLACK CLAY

\section{YELLOW GRAVELS W/CLAY/ASH/CHARCOAL}

Figure 7. West wall profile, Trench 5. 
that was a brown clay loam to $84 \mathrm{~cm}$ bs. The bottom layer of the acequia channel consisted of mottled yellow clay, ash, and charcoal. Unlike Trenches 2-4, the bottom of the ditch did not reach caliche. Instead, at this point the initial construction only penetrated the black clay to achieve the surveyor's desired grade. The wooden post was set eight centimeters into the clay. The wood-lined channel appears to have been confined to a narrower $(86 \mathrm{~cm})$ channel at this point. As in Trench 4, the density of early twentieth-century artifacts was less than in Trenches 2 and 3.

\section{Trench 6}

The southwest corner of Trench 6 was $99.5 \mathrm{~m}$ east of South Flores Street and $109.7 \mathrm{~m}$ south of West Sheridan Street. This trench was $3.7 \mathrm{~m}$ long and $66 \mathrm{~cm}$ wide, on a magnetic north bearing of 87 degrees (Figure 3). Backhoe Trench 6 revealed a rusted-metal, $2.54-\mathrm{cm}$ (1-inch) water pipe; pieces of clear glass; and PVC for a sprinkler system occluded within typical brown loam to a depth of $20 \mathrm{~cm}$. The clayey loam sediments then changed to sterile black clay at $50 \mathrm{~cm}$ before contacting caliche at $90 \mathrm{~cm}$ bs. No historic cultural material was found in Trench 6.

\section{Trench 7}

The southwest corner of Trench 7 was $88.7 \mathrm{~m}$ east of South Flores Street and $124.4 \mathrm{~m}$ south of West Sheridan Street. This trench was five meters long and $66 \mathrm{~cm}$ wide, on a magnetic north bearing of 120 degrees (Figure 3). The acequia was not expected to be found in this area. The top $30 \mathrm{~cm}$ was a mottled layer of loam and construction fill. From 30 to $45 \mathrm{~cm}$ bs twentieth-century debris was uncovered, including a .9-m (3-ft) standing vent pipe, a $1.5-\mathrm{m}$ (5-ft) sewer pipe, concrete block fragments, a $2.54-\mathrm{cm}$ (2-inch) gas line, a $5-\mathrm{cm}$ (1-inch) PVC line with cable inside, terrazzocovered concrete fragments, and green bath tiles. The sediments below $45 \mathrm{~cm}$ consisted of sterile brown loamy clay before changing gradually to sterile black clay at $60 \mathrm{~cm}$, and then to sterile caliche at $100 \mathrm{~cm}$. No significant cultural material was found in Trench 7 .

\section{Shovel Tests 1-6}

Six shovel tests were placed in the bottom of Trench $2,1.5 \mathrm{~m}$ apart. The intent was to test the width, breadth, and contents of the buried acequia. The tests revealed a profile not unlike that illustrated in Frkuska (1981:Figure 4), and subsequently confirmed by our excavation of Units A and B (see below). The results from shovel testing verified the center of the channel and were used to strategically position two handexcavation units.

\section{Excavation Unit A}

A unit datum was established on the bottom of Trench $2(50 \mathrm{~cm} \mathrm{bs})$ centrally located between Units $A$ and B. Unit A was a .5-x-2-m unit, excavated by hand, in the northeast corner (Figure 3). The southwest corner of Unit A is $71.3 \mathrm{~m}$ east of South Flores Street and $92.7 \mathrm{~m}$ south of West Sheridan Street. The unit was strategically positioned to expose a perpendicular, 2 -m-long profile of the acequia (Figure 8).

Hard-packed gray, sandy clay with dense inclusions of broken glass and ceramics, rusted metal, and pieces of bone was encountered $50-60 \mathrm{~cm}$ bs. A vertical wooden plank varying in width from one to four centimeters emerged in profile and plan view from $50-58 \mathrm{~cm}$ bs on the western edge of the unit. Just below and beside the plank, the top of a post began to appear. Between 60-70 cm bs the soil changed to a darker gray, loamy clay, with a higher density of artifacts in the eastern half of the unit. Artifacts included pieces of metal, glass, and red and yellow bricks, as well as an iron bedstead.

The post on the west edge of the unit continued downward, and a second, broken plank was identified just inside the post at $62 \mathrm{~cm}$ bs. This fragmented plank appeared to have been snapped, since it veered off at a 45 degree angle to the northwest; not following the line of the plank above it. From $70-80 \mathrm{~cm}$ bs the soil became a loosely packed dark gray clay. Red and yellow brick, glass, heavy amounts of charcoal, rusted metal, numerous snail shells and a few buttons were found in this layer. Once again, most of the artifacts came from the 

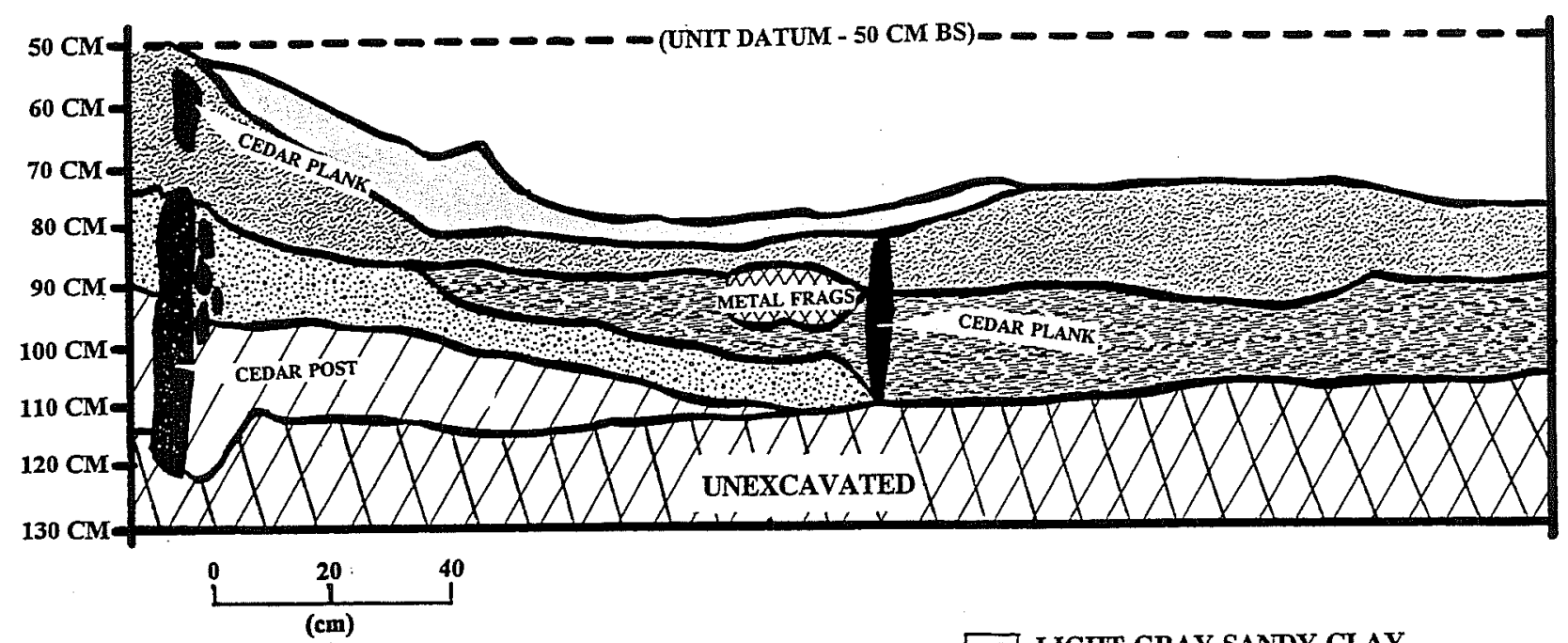

LIGHT GRAY SANDY CLAY

GRAY CLAY

GRAYISH BLACK CLAY W/CHARCOAL

CALICHE/CLAY MIXX

CALICHE

Figure 8. North wall profile, Excavation Unit A.

eastern half of the unit. A third, severely deteriorated plank, varying in width from 1-3 $\mathrm{cm}$, and $116 \mathrm{~cm}$ east of the other two was encountered at $71 \mathrm{~cm}$ bs.

Between 80 and $90 \mathrm{~cm}$ bs, the soil abruptly changed to a loosely packed, gray, clay and caliche mix in the west end of the unit. Although snail shells were distributed evenly throughout, the density of artifacts decreased significantly except for an amorphous mass of rusted metal appearing in the north wall profile at approximately $85 \mathrm{~cm}$ bs. The sediments were a lighter gray outside the plank "walls." The western lower plank became severely deteriorated and fragmented but the post was still fairly well preserved at $90 \mathrm{~cm}$ bs.

It was obvious that the acequia had been woodlined in this area. The unit excavation continued from 90 to $100 \mathrm{~cm}$ bs. The depth of the top of the hard-packed, yellow caliche varied from $85 \mathrm{~cm}$ in the western half to $100 \mathrm{~cm}$ bs in the eastern half of the unit. The eastern vertical plank continued to $91 \mathrm{~cm}$ bs. Inside the plank walls was a gray, clay and caliche mix. The stratigraphic relationships in the profile indicate that the acequia was originally dug through loam and clay sediments and sometimes reached the caliche in order to keep the water flowing. At this point the width of the acequia had been up to nine feet until its channel was restricted by wooden plank and post lining.

\section{Excavation Unit B}

A unit datum was established on the bottom of Trench $2(50 \mathrm{~cm}$ bs) centrally located between Units A and B. This unit was a .5-x-2-m unit, excavated by hand, and situated in the southwest corner of Trench 2 (Figure 3). The southwest corner of Unit B is $66.75 \mathrm{~m}$ east of South Flores Street and $95.4 \mathrm{~m}$ south of West Sheridan Street. The unit was strategically placed so as to expose a 2-m-long perpendicular profile of the acequia.

Yellow clay and other gravels-with inclusions of ceramics, bone, and corroded metal-was encountered within the first $60 \mathrm{~cm}$ bs (Figure 9). 


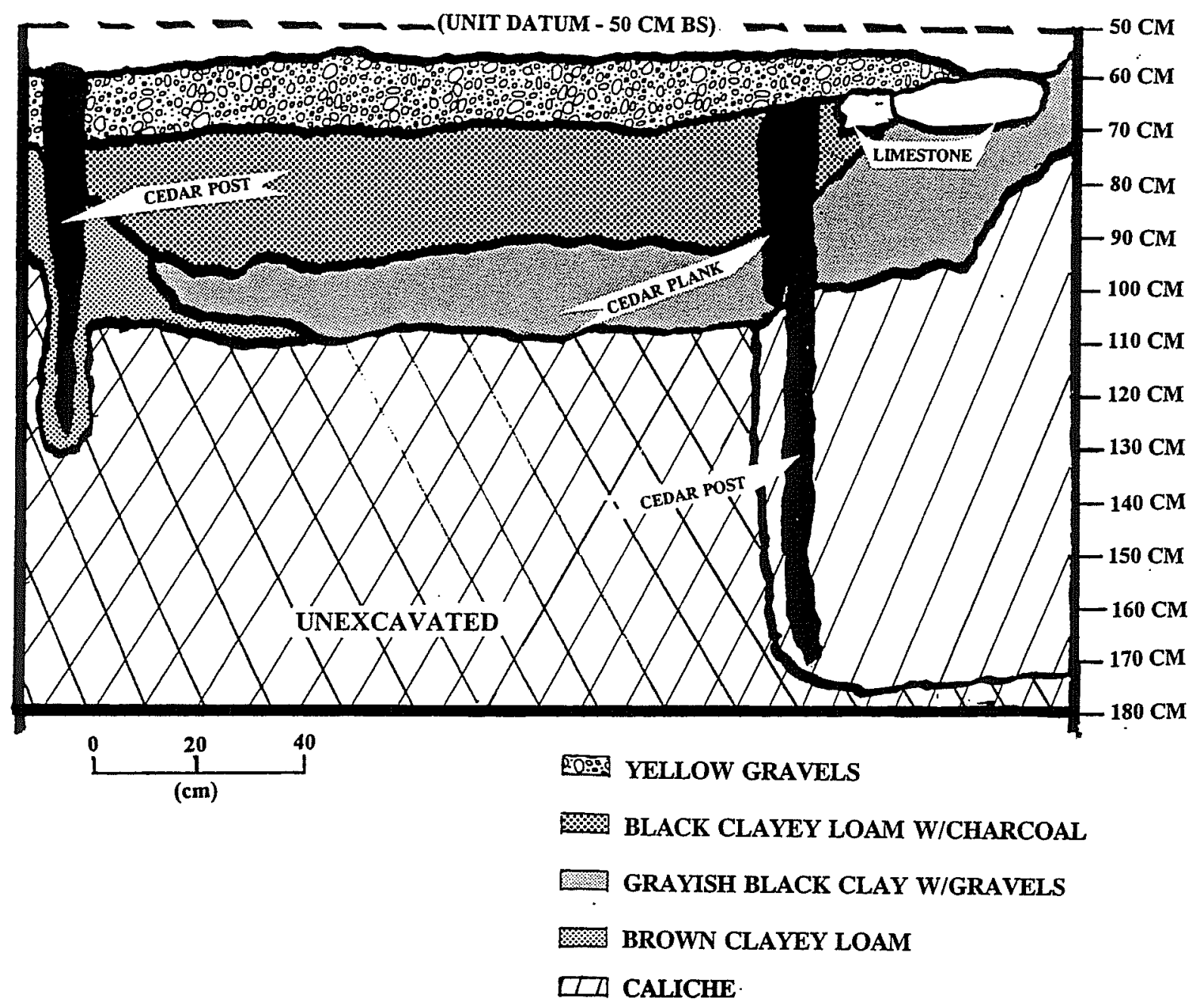

Figure 9. South wall profile, Excavation Unit B.

The upper end of a deteriorated cedar post up to $10 \mathrm{~cm}$ wide appeared in the northeast end of the unit; in the northwest end of the unit a second deteriorated cedar post ( $<6 \mathrm{~cm}$ width) appeared (Figure 9). The two posts were $116 \mathrm{~cm}$ apart and were evidently an extension of the wood lining being uncovered simultaneously in Unit A. The posts continued downward to the $60-\mathrm{cm}$ level, while the sediment changed to a black clayey loam mixed with charcoal at the same level. Outside the west wall of the acequia were $10-\mathrm{cm}$ thick, uncut, flat stones. They may have been used for either bridging or shoring the walls of

the acequia; the reason is unclear. Underneath the stones, the outline of a cedar plank which was broken and veered at a 45 degree angle to the acequia path was discovered. Ceramics, bone, metal, and glass were present throughout this level, with the predominance of material coming from inside the acequia's walled channel.

Another layer consisting of gray-black clay with gravels was found at the 80-cm level. Excavation was continued to the caliche acequia floor at 
$96-100 \mathrm{~cm}$ bs. The usual early twentieth-century trash deposits of ceramics, bone, metal, and glass were present to floor depth. The bottom of the cedar board was at $93 \mathrm{~cm}$ bs. Excavation continued around both cedar posts so they could be collected. The eastern post was set $30 \mathrm{~cm}$ into the caliche; the western post, $60 \mathrm{~cm}$. The difference in depth of the two posts may be attributed to two factors: 1) a dense concentration of large gravels outside the eastern wall may have been placed there as additional reinforcement; and 2) the acequia appears to begin a turn to the south here, thus exerting greater fluvial pressure on the western wall.

\section{Discussion}

Seven trenches, six shovel tests and two .5-x-2-m excavation units were placed in the area during the 1994 project (Figure 3). Cedar planks and/or fence posts that comprised the walls of a woodlined acequia channel were encountered in four of the trenches (2-5) and both excavation units (A and B). The top of the acequia is now $50 \mathrm{~cm}$ below the modern surface. Its walls were constructed of 2-x-10-inch cedar planks reinforced on the outside by 6 -inch cedar posts. Two-by-four-inch wooden scantling spanning the top was held in place by spikes driven into the top of the posts, further reinforcing the structure. Cobbles and gravels were used as shoring on the outside wall curvatures (Figure 10). No manufactured flooring was necessary. The acequia was simply dug into packed caliche to a depth necessary to insure the gravitational flow of water. Natural and cultural depositions outside the planked walls suggest that the wooden channel was of later construction and placed in an earlier, wider channel dug into the clayey soils.

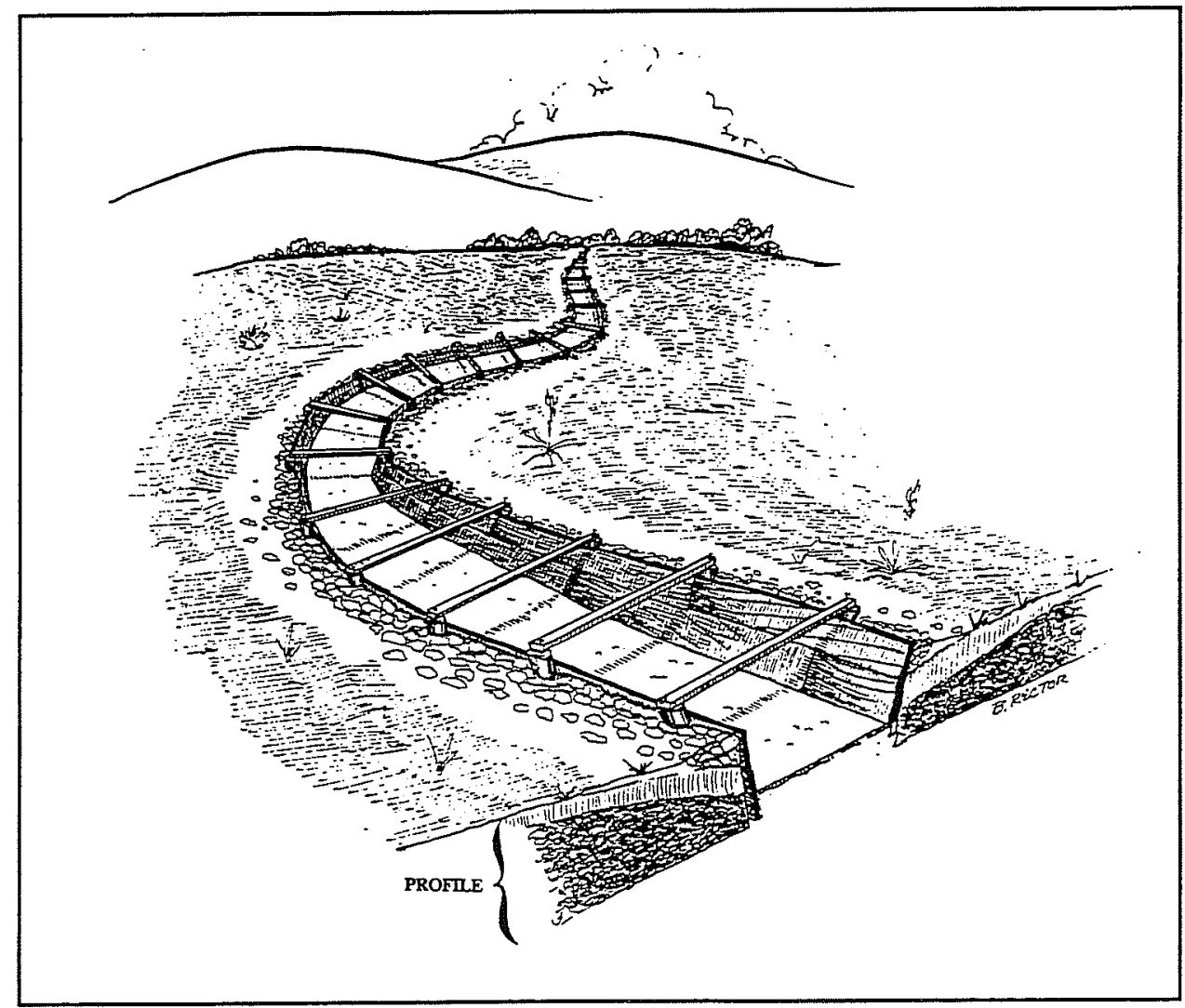

Figure 10. Artistic reconstruction of the wood-lined San Pedro Acequia, based on archaeological data. 


\section{Artifact Analysis \\ Connie Gibson}

\section{Introduction}

Due to the early settlers' reliance on the San Pedro Acequia, it was clean and well kept for almost a century after its construction. The acequia was an essential component of the agricultural irrigation system, and was kept in good repair and cleaned out annually. These cleanings clearly affected the artifactual record, as no items from the eighteenth century were recovered during the excavation.

The acequia first began to suffer neglect in the early 1800 s. From the 1860 s through the early $1900 \mathrm{~s}$, the acequia operated as a combination irrigation water source, refuse disposal, and storm water runoff facility. It was cleaned out and maintained periodically, however, again diminishing the artifactual record.

In 1906 the water stopped flowing, and in 1912 the acequia was officially closed. The historic San Pedro Acequia, so vital to the welfare and stability of the early settlers, came to serve the citizens of San Antonio as a refuse dump. It was not until the acequia fell into disuse that it began to accumulate the trash that we recovered in our excavations.

Artifacts recovered during the San Pedro Acequia project were cleaned, labeled, and cataloged, and are stored at the CAR laboratory. The total artifact count is 5,431 items. In addition, over five kilograms of scrap metal, coal, clinkers (chunks of coal which did not burn completely), and charcoal were recovered.

\section{Methodology}

Sediment from the excavation units and shovel test was screened in the field using $1 / 4$-inch wire mesh screens. Fill from Trenches 1-3 was not screened but artifacts were collected. Artifacts were collected in field bags, labeled with provenience unit and depth, and transported to the laboratory for processing.

All items were washed (except charcoal), stored in plastic bags, and labeled with permanent ink on acid-free paper. All diagnostic artifacts, such as ceramics, whole bottles, and glass or metal items with embossed lettering, were labeled individually.

Artifacts were categorized, cataloged on worksheets, and entered into a computer database. Totals and relative percentages of the various categories of artifacts were calculated on spreadsheets. Research was conducted to formulate a range of dates for deposition of artifacts and to identify unique artifacts. The catalog worksheets, computer database, and spreadsheets were continually updated as items were reclassified.

The artifacts were first grouped into general categories of Ceramics, Glass, Toys, Personal, Clothing, Household, Activities, Construction, Barn and Workshop, Utilities/other construction, Arms, Prehistoric, Bone/organics, and Miscellaneous. Table 2 details the number of artifacts found in each of the excavation units, and the percentage of each category of artifacts to the total number recovered during the operation.

Ceramics were divided into subcategories, intact glass bottles were inventoried, and bottle glass was classified by color. A chronological range of dates for deposition of artifacts was constructed based on the documented history of the acequia, manufacturing dates of ceramic artifacts with makers' marks, analysis of mold seams and lips of glass bottles, and analysis of other diagnostic artifacts. 


\begin{tabular}{|c|c|c|c|c|c|c|c|c|c|c|c|c|c|c|c|c|c|}
\hline 4 & $\frac{6}{6}$ & $\frac{6}{4}$ & 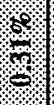 & 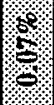 & $\frac{6}{6}$ & . & 8 & 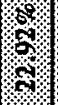 & $\frac{6}{8}$ & \% & $\frac{6}{6}$ & 8 & $\frac{8}{3}$ & \% & & 3 & \\
\hline 8 & $\sqrt[8]{1}$ & 9 & ?. & . & צी. & א. & $1 \%$ & 8 & 6. & (4) & 6 & \%. & 8 & $\sqrt{1}$ & \%ั & 6. & 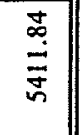 \\
\hline 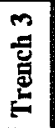 & - & $m$ & & & & & & + & $\stackrel{\circ}{n}$ & & - & & & & 6 & 约 & $\stackrel{8}{\circ}$ \\
\hline 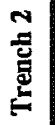 & $\stackrel{2}{m}$ & $=$ & - & & & & & & - & & & & & & (2) & 8 & $\stackrel{8}{\circ}$ \\
\hline $\bar{\Xi}$ & $=$ & $a$ & & & & & & & $\infty$ & & & & & - & \% & 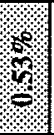 & $\begin{array}{l}8 \\
\underline{\dot{b}} \\
\end{array}$ \\
\hline$\ddot{b}$ & & & & & & & & & & & & & $m$ & & 91 & 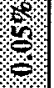 & $\begin{array}{l}8 \\
0\end{array}$ \\
\hline in & $\simeq$ & $\approx$ & - & & - & - & & $n$ & 导 & & $\nabla$ & & 으 & - & 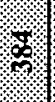 & 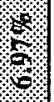 & 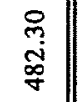 \\
\hline 5 & $a$ & $\stackrel{m}{\circ}$ & & - & & 0 & & 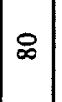 & 吉 & & $m$ & & $n$ & $N$ & 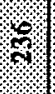 & \% & $\frac{8}{\infty}$ \\
\hline$\frac{m}{5}$ & 0 & $\stackrel{\sim}{*}$ & - & & $\sim$ & $N$ & & $\approx$ & is & & - & - & & & ㅎิ & 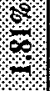 & $\begin{array}{l}\infty \\
\infty \\
\dot{\infty}\end{array}$ \\
\hline 点 & & - & & & & & & - & $\approx$ & & & - & $N$ & & \% & 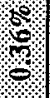 & $\begin{array}{l}8 \\
0 \\
0\end{array}$ \\
\hline 5 & & & & & & & & & $\approx$ & & & & & & \% & : & $\stackrel{R}{0}$ \\
\hline 苟 & $\vec{\nabla}$ & 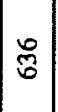 & $\infty$ & - & $\nabla$ & $m$ & $N$ & $\frac{n}{n}$ & $\stackrel{\infty}{\infty}$ & $\sigma$ & 2 & & 8 & $a$ & 8 & 4 & $\begin{array}{l}\overrightarrow{\dot{D}} \\
\frac{\dot{\sigma}}{+}\end{array}$ \\
\hline 号 & $\stackrel{\infty}{\unrhd}$ & $\frac{\infty}{n}$ & 0 & $N$ & $\infty$ & $\infty$ & $m$ & 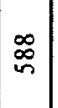 & $\widetilde{\Xi}$ & 인 & $N$ & -1 & 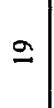 & $\infty$ & 8 & 3 & 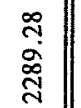 \\
\hline & 总 & $\begin{array}{l}n \\
\tilde{m} \\
\mathbb{J} \\
0\end{array}$ & 密 & 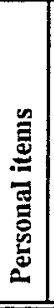 & 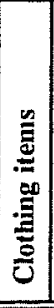 & 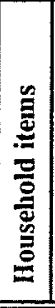 & 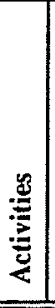 & 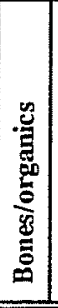 & 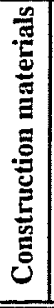 & 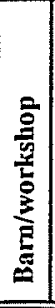 & 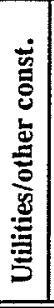 & 节 & 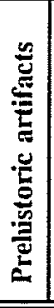 & 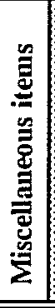 & : & צla & 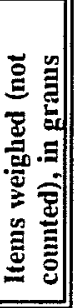 \\
\hline
\end{tabular}




\section{Results}

The artifact assemblage from the acequia consists of historic and prehistoric components (Table 2). The prehistoric component-102 chert flakes and chips-accounts for 1.85 percent of the total artifact count. No formal prehistoric tools were found. The historic component comprises the majority of the collection, 98.15 percent of the total artifact count.

The artifacts recovered from the acequia in greatest number were construction materials $(n=2,225)$; followed by glass $(n=1,311)$; faunal and other organic remains $(n=1,263)$; and ceramics $(n=470)$. The artifact retrieved most in terms of sheer volume was scrap metal, believed to be largely the remains of tin cans. General categories and specific individual artifacts are discussed below.

\section{Ceramics}

Ceramic artifacts $(n=470)$ make up 8.5 percent of the total artifact count. Unfortunately, no ceramic vessels were recovered intact. Although various sherds were crossmended, it was impossible to restore any item in its entirety.

Ceramics were categorized for analysis primarily according to technological attributes, and secondarily by stylistic attributes. Paste, surface treatment, hardness, and degree of vitrification resulted in three broad separations of earthenware, stoneware, and porcelain.

Within the three broad divisions, earthenwares consist mostly of whitewares which were broken down into decorated and undecorated groupings. The decorated whitewares were assigned types based on techniques employed for surface decorations, i.e. embossing, handpainting, banded slip, etc. Rim diameters of measurable sherds were estimated using a rim diameter chart.
Table 3 gives a breakdown of ceramic artifacts with the basic categories used to classify the ceramic sherds, the number and provenience of different types of ceramics found, and each category's percentage of the total ceramic artifact count. Most ceramics from the San Pedro Acequia ( $\mathrm{n}=279,59.36$ percent) are lightcolored, hard-paste, refined earthenware, without paint or surface decoration, designated undecorated whiteware (Dial 1992:38-39). Decorated whitewares $(n=62)$ make up 13.2 percent of the ceramic category. Various ceramic decorative techniques are represented, as indicated in Table 3. Stoneware $(\mathrm{n}=84)$ comprises 17.87 percent of the ceramic assemblage, and porcelain $(n=40)$ makes up 8.51 percent. Unrefined ceramics $(n=4)$ are scarcely represented in the collection.

Ceramic sherds bearing a maker's mark, or of an identifiable pattern, are extremely useful for dating. Several sherds with makers' marks from the acequia provide an excellent range of manufacturing dates.

\section{Earthenwares}

Unrefined

Only four sherds of soft-paste, unrefined earthenware were recovered: two sherds of unglazed pottery, and two red-brown clay sherds with lead glaze. These earthenwares are usually wheel-thrown with low-fired clays. Lead- and tin-glazed pottery is associated largely with Mexican artisans, the glaze technique introduced to Indian potters in Mexico through the Spanish conquest around 1520 (Dial 1992:32).

\section{Refined}

Whiteware is a hard-paste earthenware composed of highly fired, refined clay with vitreous glazing, and may be either plain or decorated. It was originally introduced in Britain in the $1760 \mathrm{~s}$ as creamware, and evolved into whiteware by 1830 (Miller 1991:1). American 


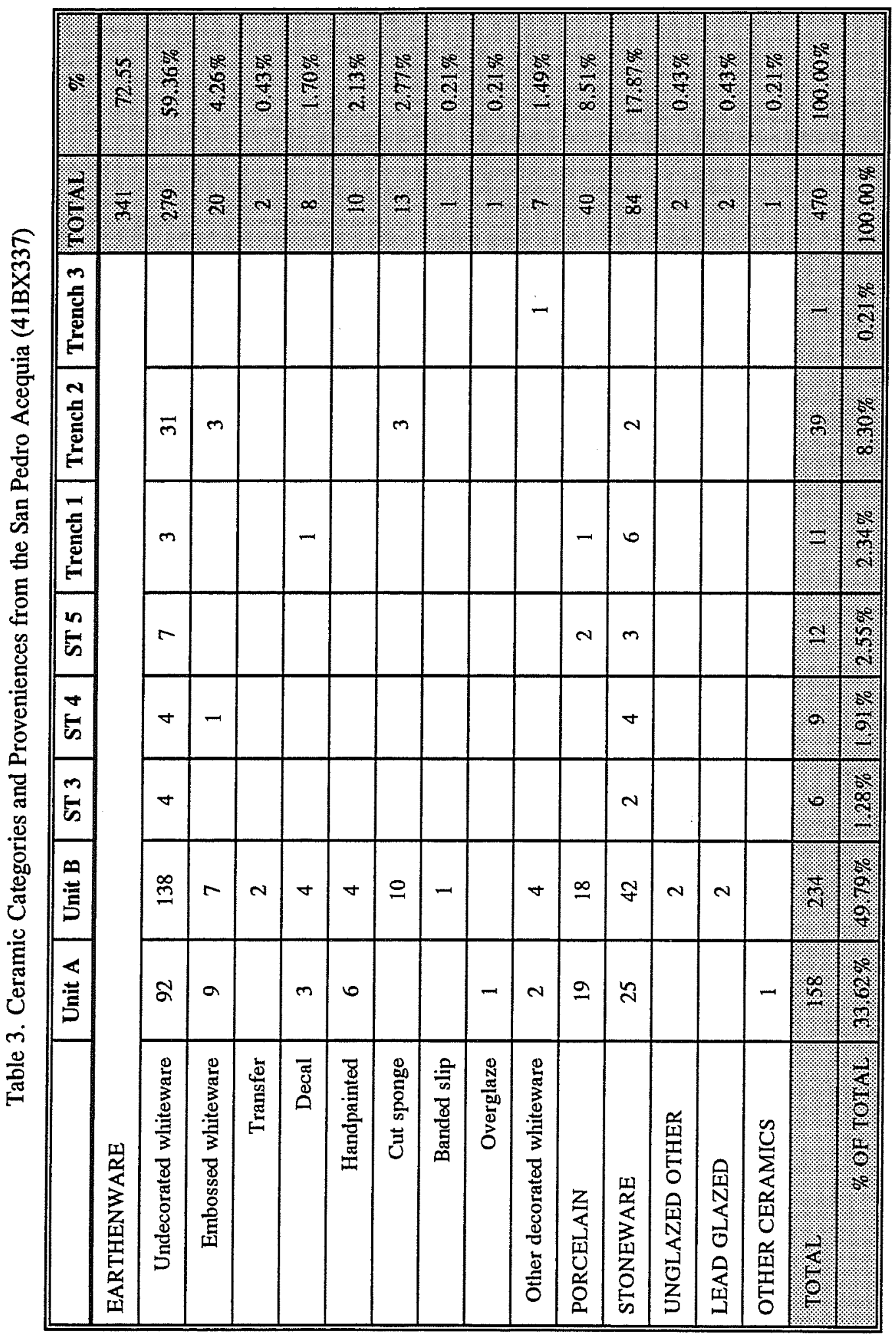

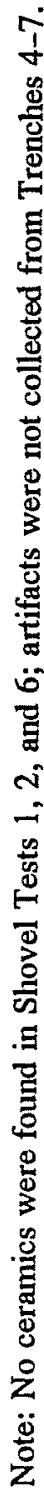


whiteware industries developed in Ohio and New Jersey; these became industrial pottery centers of the nation during the period 1850-1900 (Guilland 1971:63). The 1860s saw an increase in demand for plain undecorated tableware, and a large proportion of undecorated whiteware in an assemblage suggests post-1860s deposition (Fox et al. 1989:45).

The clays used in the manufacture of whiteware range from cream to shades of gray, and are covered with a clear to bluish glaze (Dial 1992:38). The majority of whiteware sherds taken from the acequia appear plain white with a clear shiny glaze. Several pieces have been burned.

Undecorated. Undecorated whiteware comprises 59.36 percent $(n=279)$ of the ceramics. The collection includes partial plates, bowls, cups, and saucers. Rim pieces include a dinner plate sherd, two deep saucer sherds, and three coffee cup sherds. The dinner plate would have had an estimated diameter of $22 \mathrm{~cm}$, the saucers $15 \mathrm{~cm}$, and the coffee cups $9 \mathrm{~cm}$. Several pieces appear to be hotelware, a thicker and heavier whiteware with a harder paste (Dial 1992:38).
The span of manufacturing years for the acequia undecorated whiteware begins in 1859 with a maker's mark from Rouse \& Turner of Jersey City, New Jersey. This mark-a lion and unicorn flanking an oval-shaped shield with a crown on top-was used from 1859 until operations ceased in 1892 (Thorn 1947:146).

The aforementioned deep saucer sherds show portions of makers' marks identified as Goodwin Bros. of East Liverpool, Ohio (Figure 11a). The Goodwin family has been associated with the pottery business in both Ohio and New Jersey since 1844. John Goodwin began operations in East Liverpool, Ohio, in 1844, but later sold the pottery and moved to Trenton, New Jersey. He returned to East Liverpool and began preparations to manufacture whiteware, but died in 1875. His son James began whiteware production in 1876 and continued to operate under the Goodwin Bros. name until 1893 (Lehner 1988:175).

Both marks on the recovered saucer sherds show a ring of crosses surrounding a small circle holding an eagle. These sherds are probably pieces of Pearl White ware, an ironstone dinnerware produced ca. 1885-1897 (Kovel 1986:76):

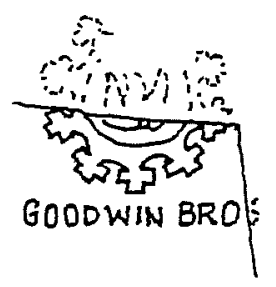

a

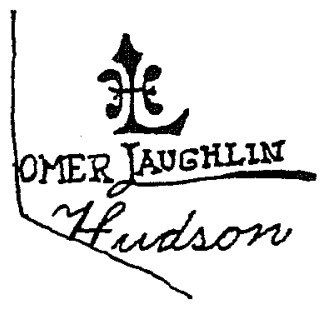

b

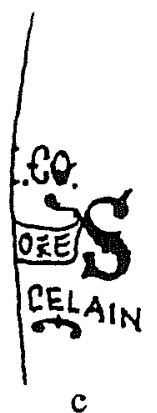

Figure 11. Makers' marks on ceramics. a. Goodwin Bros; b. Homer Laughlin China Company; c. Ohio China Company. All shown actual size. 
Another easily discernible maker's mark is the stylized "H-L" of the Homer Laughlin China Company of East Liverpool, Ohio, and Newell, West Virginia (Figure 11b). The Homer Laughlin China Company had its beginnings in 1869. It operated under that particular name beginning in 1897 and continuing to the present (Lehner 1988:245). The company is famous for its hotelware. The term "Hudson" written in script beneath the Homer Laughlin mark denotes the pattern name of the dinnerware. The Hudson pattern was made just before and after the year 1900 (Lehner 1988:247).

Another maker's mark was identified as belonging to the Ohio China Company of East Palestine, Ohio (Figure 11c). Ohio China Company operated from 1886 until 1912 (Kovel 1986:18). They used as a trademark the initials of the company, "OCCO," above the name "Limoges" and the name of the ware, in this case, "PORCELAIN" whiteware (Thorn 1947:140).

The "reclining sphinx" maker's mark of Petrus Regout \& Company of Maastricht, Holland (Figure 12a) is the only ceramic mark that could be identified as a European import; the remaining whiteware with makers' marks was of domestic manufacture. The sphinx marks were used from 1891-1931 (Kovel 1986:105, 127).

One manufacturer's mark is particularly striking, showing a reclining unicorn (Figure 12b); another mark shows only a unicorn's horn (Figure 12c). Both marks remain unidentified at the time of publication.

Decorated. Decorated whiteware sherds make up 13.19 percent of the ceramic collection $(n=62)$. Figure 13 illustrates selected sherds of decorated whitewares from the acequia assemblage. The decorated whitewares include embossed, transfer-printed, decalcomania (decal overglaze), hand-painted, cut sponge-painted, and banded slip wares. A general category was added for other decorative techniques and for special known patterns such as the Tea Leaf dinnerware pattern. No manufacturer's marks were found on any of the decorated wares.

Embossing is a technique used to mold patterns into ceramics, causing some areas to become raised and some lowered, forming reliefs. Embossing was frequently used as edge decoration on serving bowls and platters. Twenty sherds showing embossing are among the acequia artifacts.

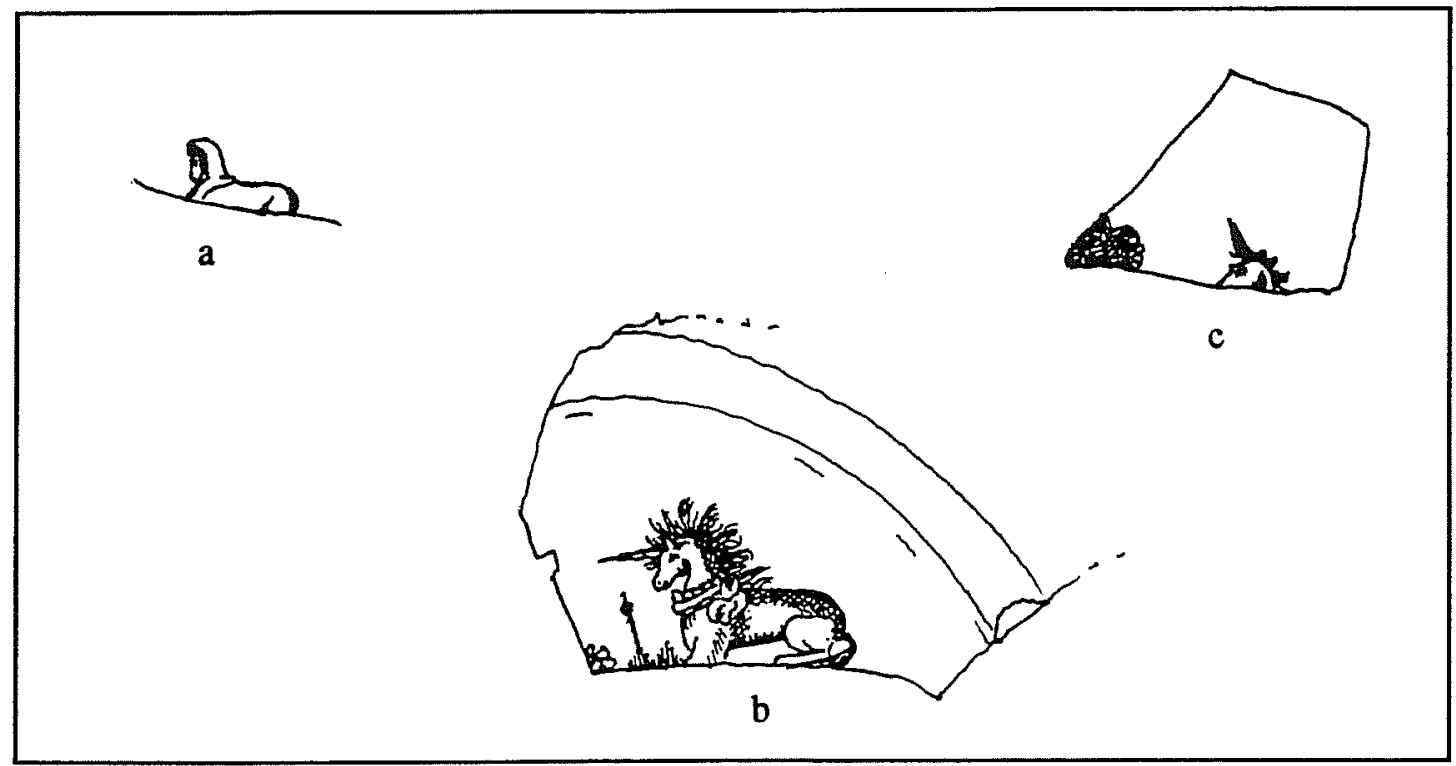

Figure 12. Makers' marks on ceramics. a. Petrus Regout \& Company; b., c. unidentified. All shown actual size. 


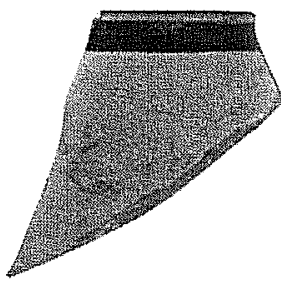

a
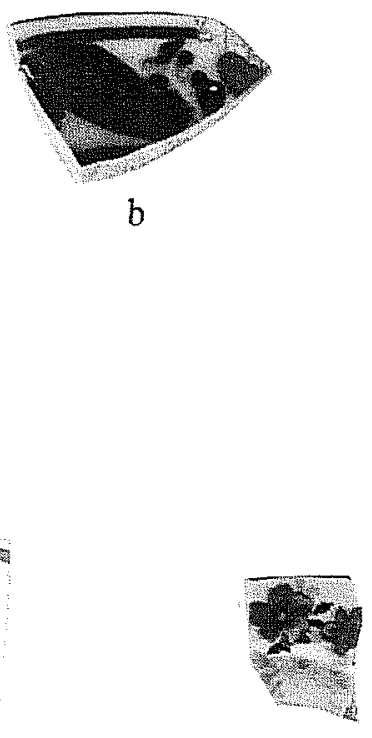

e

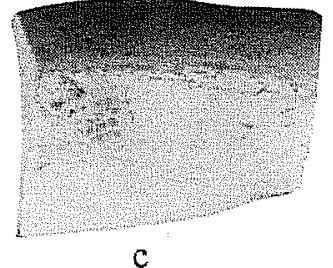

c
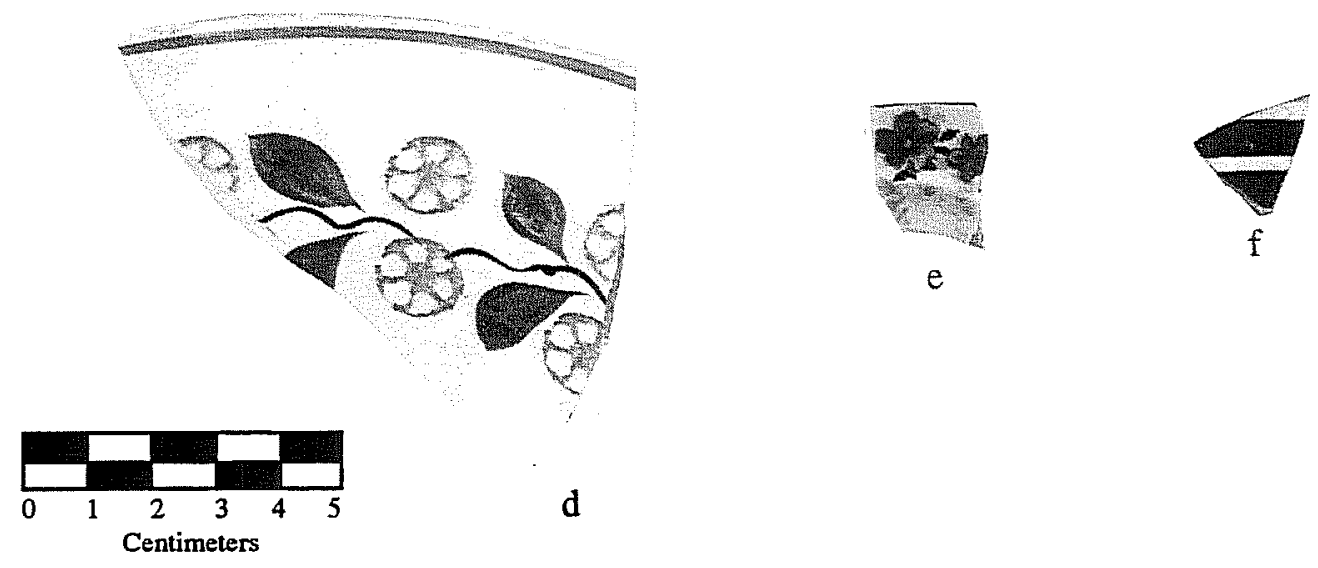

d

Figure 13. Decorated whiteware. a. Tea Leaf ironstone; b. handpainted; c. decorated edge; d. cutsponge painted; e. decal decorated; f. banded slip.

In some instances, a ceramic item exhibits several different decorative techniques, although classified in only one; such is the case with a large white vessel believed to have been a chamber pot (Figure 14). The vessel is embossed and has a decal print of large blue flowers applied over-glaze, with a thin line of gold paint encircling the rim. Holes are present on the sides, apparently for attaching a wire handle for carrying. Sherds of a matching lid were also found.

Decalcomania, or decal, is a technique where decals are applied over the glazed ceramic (Figure 15). Decal ware was manufactured commercially in the U.S. beginning around 1890, (Fox et al. 1989:45). Eight sherds from the acequia were classified as decal ware.
Two sherds of whiteware were determined to be transfer decorated. This is a technique which uses copper plates to engrave a design on the ceramic; then it is inked and glazed. Transfer ware is denoted by under-the-glaze decorations.

Ten sherds of handpainted whiteware were recovered. In addition, 13 other sherds of handpainted ceramics using the cut-sponge technique were collected. With this technique, carved sponge stamps are used to create repetitive colorful designs. The cut-sponge sherds from the acequia mostly adhere to a single pattern of green leaves, bright pink cutsponge flowers, and flowing black lines (Figure 13d). 


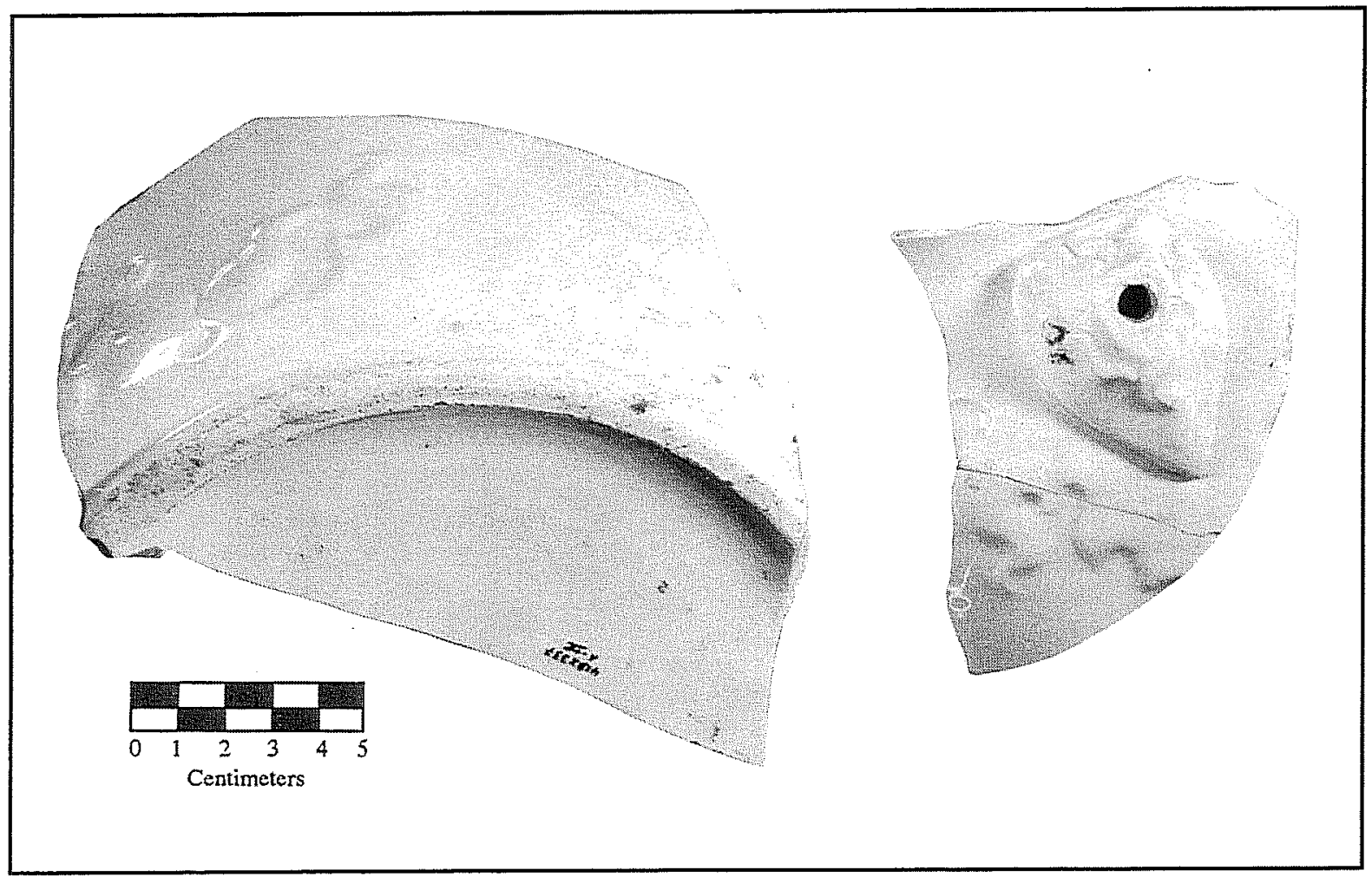

Figure 14. Probable chamber pot.

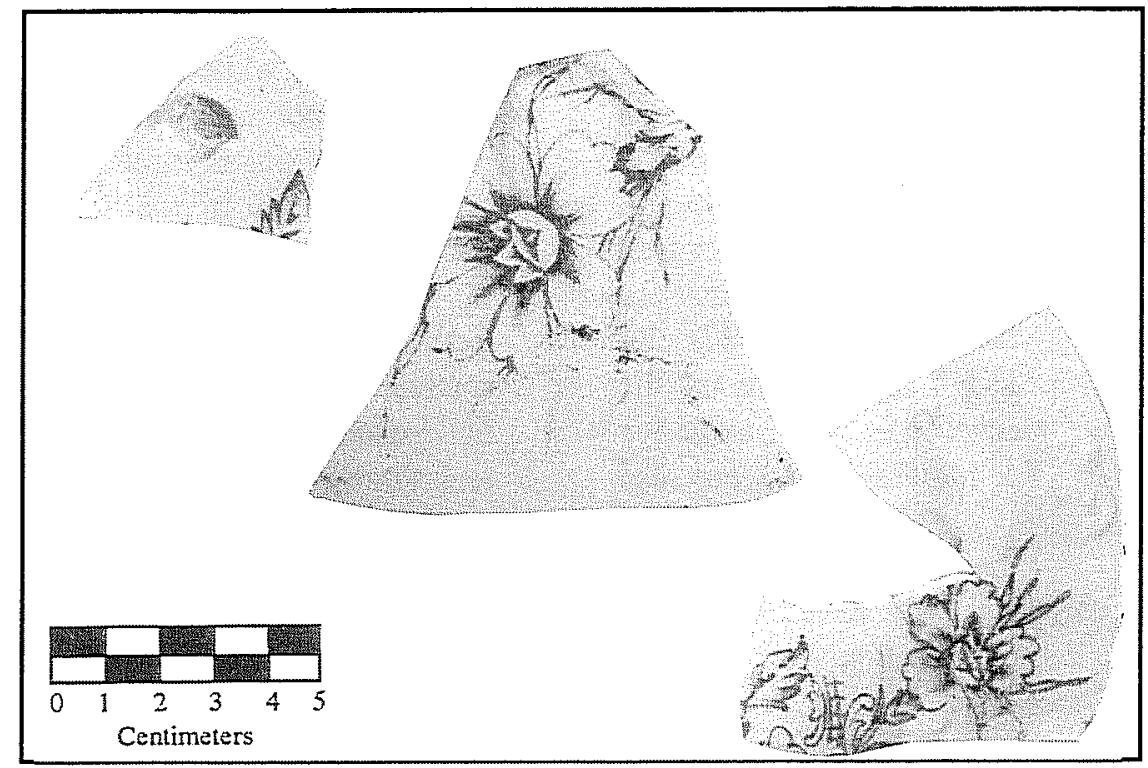

Figure 15. Decalcomania. 
Among the decorated whitewares is a single sherd of banded slip ware (Figure 13f), a decorative technique using symmetrical single or multiple bands of colored slip as decoration around the rims of vessels. This sherd has double black bands on a gray background.

A single fragment of the Tea Leaf pattern dinnerware was found (Figure 13a). Tea Leaf is a design first introduced on whiteware in England in the mid 1800 s. It became prevalent in America when housewives adopted slightly decorated wares rather than plain, utilitarian whitewares. The traditional Tea Leaf pattern appears as a bud with a flowery sprig of leaves in copper luster on a plain white background, often with a band around the rim. American potters in Ohio began turning out Tea Leaf dinnerware in the mid to late $1800 \mathrm{~s}$, and continued until interest waned around 1900 (Brazosport Archaeological Society Newsletter, Vol. VI, No. 10, July 1987). The Tea Leaf sherd in the acequia collection is a small rim sherd with a single band, and is badly burned.

\section{Stoneware}

Stoneware is a strong utilitarian pottery used particularly in dairies and kitchens, and is well represented in the acequia collection, at 17.87 percent $(n=84)$ of the total ceramics. Whereas earthenware is often formed from a mixture of clays, stoneware is usually formed from one kind of natural clay. Depending on the locale, clay colors range to shades of cream, gray, and brown. The vessels are highly fired at temperatures between $1200^{\circ}$ and $1400^{\circ} \mathrm{C}$. This produces a dense, vitrified, opaque, waterproof vessel that requires no glazing on the interior to prevent leakage, although a glaze is usually applied on both the interior and exterior.

The acequia stoneware is mostly in the form of heavy, cylindrical crocks suitable for preparation and preservation of foods such as pickles, mincemeat, or sauerkraut; and large, wide bowls. Two of the crocks have estimated base diameters of $18 \mathrm{~cm}$; another crock has a fluted bottom with a base diameter of $17 \mathrm{~cm}$; another has a 24-cm base diameter. One bowl is gray with a brown interior, with a $25-\mathrm{cm}$ rim diameter. Another is a large mixing bowl with a rim diameter of $28 \mathrm{~cm}$, in shaded bands of brown exterior and dark brown interior.

The acequia stoneware is similar to other stoneware artifact assemblages from the San Antonio area. Nearly all the stoneware vessels are glazed on the interior with Albany Slip, a dark brown "chocolate pudding" colored glaze popular in the nineteenth century. Two sherds have the gray-white Bristol Glaze on the interior. The latter became popular around 1900, as salt glazes and Albany Slip became less favored (Hard et al. 1995:46).

Salt glazing is a technique which produces a surface texture similar to that of an orange peel, and is accomplished by throwing common rock salt into the firebox of the kiln at high heat. Several salt-glazed vessels are included in the acequia collection, in addition to three sherds of Leon Slip glazed pottery.

Leon Slip pottery is readily distinguished because of its local manufacture at the Meyer Pottery of Atascosa, Texas. The clay for Leon Slip was dug from a local source near Leon Creek, on a small hill located on what is now Kelly Air Force Base (Greer and Black 1971:4). Leon Slip is unique in its color and texture-the fired glaze appears in a wide range of colors, primarily greens and browns. Two Leon Slip sherds from the acequia are of a pale matte green color, the other sherd is a bronze color on the obverse and pink-tan on the reverse.

The Meyer Pottery began as a family business near Atascosa, Texas, in 1887 and remained in operation until 1962 (Greer and Black 1971:1). Most of the work at the Meyer pottery was done by hand. William Meyer was the master potter during the interval of peak production, from 1900-1945. While the average potter could turn out 200 gallons of ware a day and a good potter 300 gallons, William Meyer could turn out 2,000 two-inch flower pots or 100 large 10 -gallon jars 
a day, an impressive achievement (Greer and Black 1971:8).

The potter made items to order on occasion and, for a few additional cents, a name was inscribed on the vessel. The pieces most frequently marked with personal names were jugs, mugs, mixing bowls, and preserve jars. Two of the Leon Slip sherds from the acequia have been mended to form the letters " $L$ " and " $K$," with an "S" beneath (Figure 16).

\section{Porcelain}

Porcelain is a smooth, almost translucent ceramic made from a fine-grained clay that is fired at a very high temperature to create a thin, vitrified product that rings clearly when the edge is tapped against a hard surface. Porcelains were expensive and considered more desirable than plain whitewares for fancy occasions. The acequia ceramic assemblage is composed of 8.51 percent porcelains $(n=40)$. These are mostly in the form of tea cups and saucer sherds; one is a butter chip. Three of the porcelain sherds exhibit gold paint trim, and one sherd has indecipherable gold writing on a white background. One small piece of relatively inexpensive brown Japanesemade porcelain is represented. Among the porcelains, two separate flower patterns, probably in decal, are applied in shades of yellow flowers/brown leaves and pink flowers/green leaves on white backgrounds.

\section{Summary}

The dates of manufacture of ceramics recovered from the acequia tend to cluster in the last quarter of the nineteenth century. This includes both the undecorated whitewares for which we have makers' marks-and, therefore, dates of manufacture-and the decorated wares which can be dated by their patterns and methods of decoration. Allowing for the period of time between the date of manufacture of an item and its breakage and final discard, the ceramic sherds were deposited in the acequia sometime soon after 1900, but before the ditch was officially closed in 1912 .

Predominance of undecorated whiteware (59.4 percent) reflects the householders' preference for this type of tableware in the last quarter of the nineteenth century. The various types of vessels-plates, cup, saucers, and a chamber pot-are typical of a late-nineteenth-century household in San Antonio. The presence of numerous stoneware crocks and bowls was not at all unusual in San Antonio kitchens during this time. Indeed these wares reflect a strong German influence, as well as the continuing presence of a number of stoneware potteries in the vicinity.

\section{Glass}

Glass artifacts $(n=1,311)$ comprise 23.8 percent of the total artifacts recovered from the acequia. Clear, brown, and green were predominant colors in the assemblage.

\section{Whole Bottles}

Ten intact glass bottles were recovered from the San Pedro Acequia (Table 4), along with a few in nearly intact condition, with broken necks or bases. Most are for food or medicine storage. Several bottles exhibit embossing, which American glassmakers began to use on bottles to 


\begin{tabular}{|c|c|c|c|c|c|c|c|c|c|c|}
\hline 竞 & 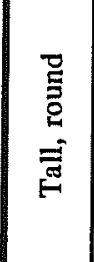 & 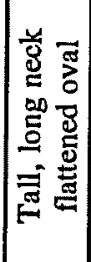 & 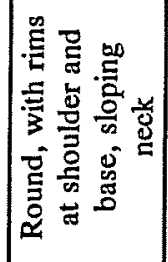 & 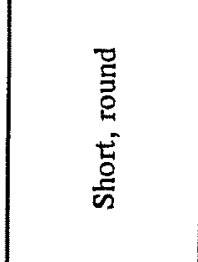 & 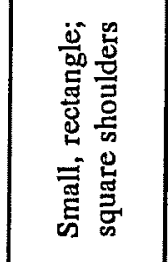 & 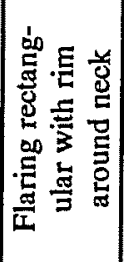 & 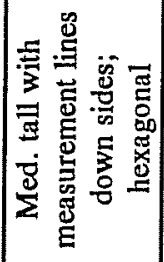 & 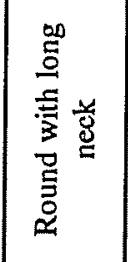 & 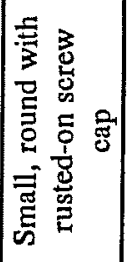 & 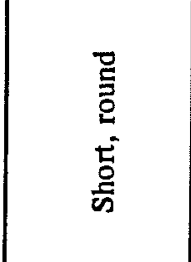 \\
\hline $\mid$ & 畩 & 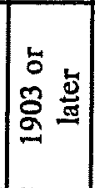 & 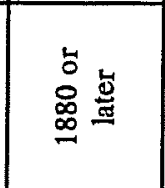 & 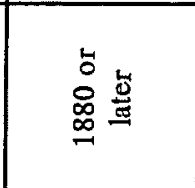 & 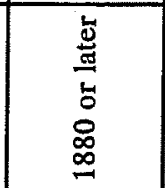 & 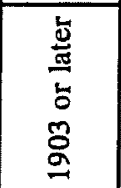 & 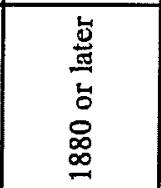 & \begin{tabular}{l}
8 \\
$\stackrel{8}{1}$ \\
1 \\
$\infty$ \\
$\infty$ \\
\hdashline
\end{tabular} & 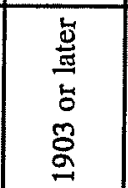 & 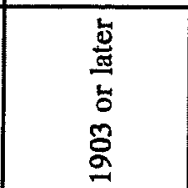 \\
\hline 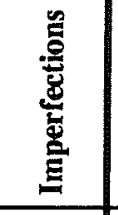 & 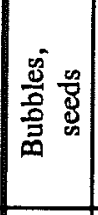 & 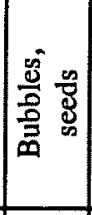 & $\stackrel{0}{\stackrel{0}{0}}$ & $\stackrel{0}{z}$ & 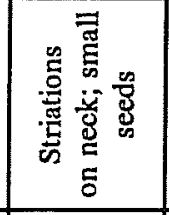 & $\stackrel{\mathscr{5}}{z}$ & 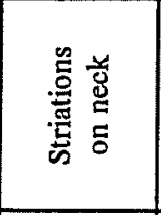 & 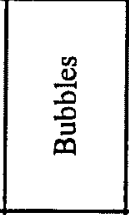 & $\stackrel{0}{Z}$ & : \\
\hline 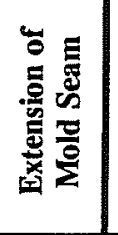 & 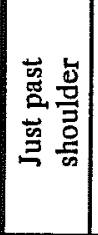 & 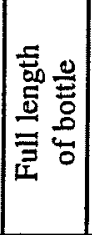 & 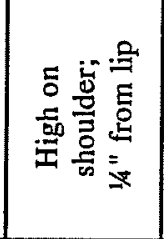 & $\stackrel{9}{0}$ & 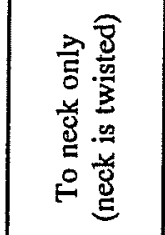 & 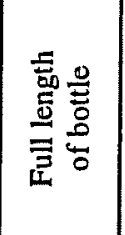 & 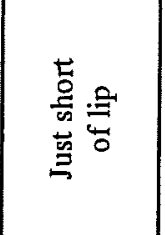 & 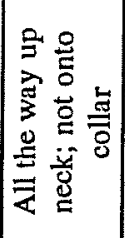 & 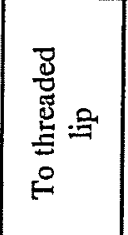 & 魚 \\
\hline$\sum_{\frac{2}{3}}^{\frac{0}{3}}$ & 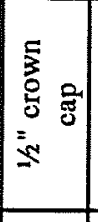 & 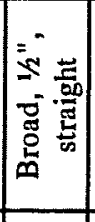 & 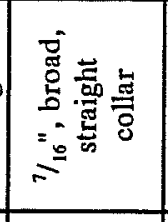 & 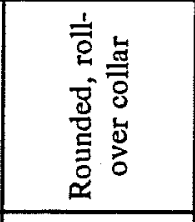 & 苞 & $\begin{array}{l}\frac{00}{E} \\
\frac{E}{E} \\
\frac{E}{I}\end{array}$ & 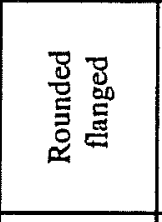 & 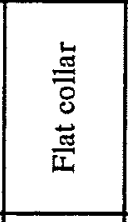 & 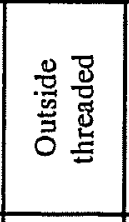 & 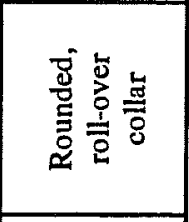 \\
\hline 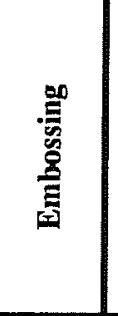 & $\stackrel{0}{z}$ & $\stackrel{0}{0}$ & 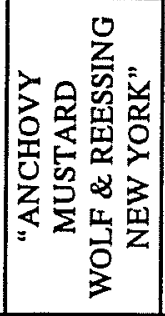 & 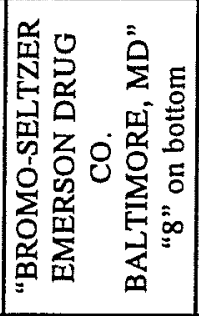 & 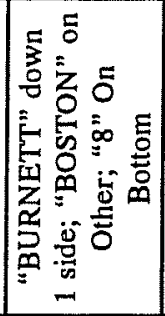 & 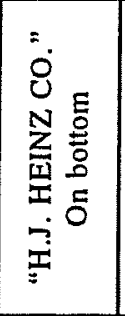 & 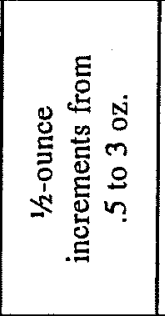 & $\stackrel{0}{\check{z}}$ & $\stackrel{0}{E}$ & 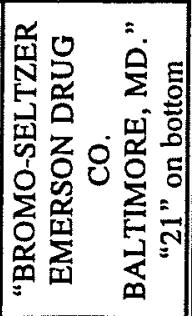 \\
\hline 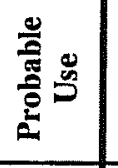 & 岛 & 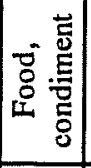 & 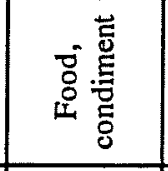 & 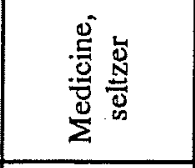 & 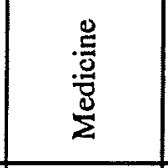 & 宫 & 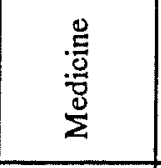 & 总晜 & 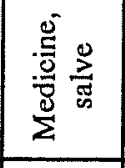 & 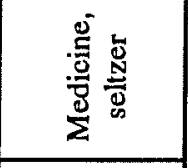 \\
\hline 章㤩 & 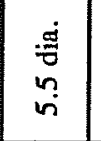 & 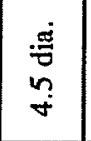 & 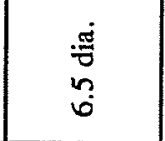 & 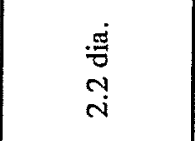 & 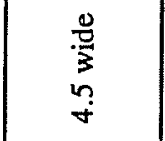 & 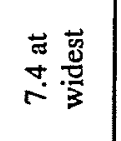 & 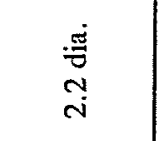 & 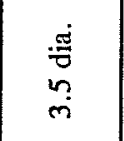 & : & 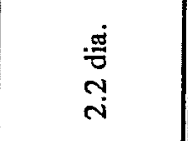 \\
\hline 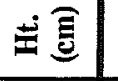 & శి & $\stackrel{\infty}{-}$ & $\underline{m}$ & $n$ & $\Rightarrow$ & $\stackrel{n}{n}$ & $n$ & \pm & $n$ & na \\
\hline$\frac{5}{8}$ & 总 & $\frac{\vec{g}}{U}$ & $\frac{\vec{E}}{U}$ & $\begin{array}{l}\overline{\bar{n}} \\
\dot{0} \\
0\end{array}$ & $\frac{\vec{d}}{0}$ & $\frac{\vec{d}}{U}$ & $\frac{\tilde{g}}{U}$ & $\frac{\breve{g}}{U}$ & 鸹咅 & 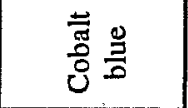 \\
\hline 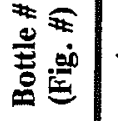 & 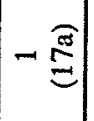 & $\sim \stackrel{\widehat{D}}{\Xi}$ & $m \stackrel{0}{\stackrel{D}{巳}}$ & $+\widehat{\stackrel{D}{E}}$ & $n \stackrel{\overparen{\Phi}}{=}$ & $0 \stackrel{\widehat{D}}{\stackrel{\infty}{=}}$ & $r \stackrel{\Xi}{\varrho}$ & $\infty$ & $a$ & 으 \\
\hline
\end{tabular}


signify contents and manufacturers around 1850 (Polak 1994:27). Embossing on bottles continued until invention of the bottle-making machine. Figures 17 and 18 illustrate selected bottles from the collection.

Dating the bottles in the acequia assemblage involved looking at mold seams, color variations, the lips and collars of the bottles, and imperfections in the glass. Before 1900 , bottles were freeblown using a blowpipe or, after 1860 , blown into a mold. In both of these processes the lip or mouth was applied, or added to the bottle after completion. An applied lip can be seen by examining the mold seam-the seam will run from the base of the bottle up the side and end just at the neck or bottom of the lip. In machinemade bottles (after 1903) the lip is formed first, and the mold seam extends all the way up the sides of the bottle and over the lip (Polak 1994:18). In most cases, the more uneven and rough the lip or top of the bottle, the earlier the bottle was made (Polak 1994:20).

As seen in Table 4, the acequia bottle collection dates from the approximate manufacturing period 1880-1920. The dark green beer/wine bottle presented an ambiguity because the mold seams extend only just past the shoulder of the bottle, very low on the neck, making it appear to have been manufactured prior to 1860 ; however, it has a crown cap. The latter-the familiar crimped metal cap still in use today-was invented in 1897 by William Painter (Polak 1994:23). Therefore, the beer bottle in question was manufactured after 1897 , making its date consistent with other bottles in the collection.

Other age factors in bottle glass are the presence or absence of imperfections and blemishes, and uneven thickness in the glass. The invention of Owens's automatic bottle-making machine in 1903 ended uneven thickness in the base. Bottle processing became more advanced around 1920, when bubbles and "seeds" were eliminated from the glass.

\section{Bottle Glass Fragments}

Another variable used for determining bottle age is color. Aqua, amber, olive green, and brown are natural colors produced in glass manufacture. Before 1880 the predominant color of bottle glass was green. With the exception of "black" glass (see below), glass color was not an important factor until around 1880 when food manufacturers began demanding clear glass containers for preserved foods (Polak 1994:24-25). Over 80 percent of the bottle glass fragments found in the acequia were clear (Table 5), suggesting post-1880s deposition.

Prior to 1860 iron slag was added to glass metal to produce a dark green glass for wine and liquids that needed to be kept from light; the resulting glass was so dark it became known as "black glass." One small fragment of what appears to be black glass was found in Unit A, at the 60-70 cm level.

The bottle-making machine invented in 1903 rendered the recycling of more expensive handmade glass bottles with molded necks and embossed lettering passe. Mass-produced clear glass bottles with inexpensive paper labels became cheap and easy to buy and discard. Trash dumps began to reflect this in an avalanche of clear bottle glass (Fox and Cox 1990:18).

One small embossed glass fragment from the acequia has been identified as a Duerler bottle. Duerler operated a candy and confections business in San Antonio from 1875 until the 1920s (Cox et al. 1990:23-25) and bottled sodas and mineral water. Other embossed items include a bottle with ". . . ANK . . . ILLER'S CROWN DRESSING, NEW YORK, USA” and a crown imprinted on the front. Another fragment is the bottom of an aqua glass jar, embossed with "KERR GLASS MFG CO, PORTLAND ORE, 3, PAT JUNE 29, 1903." 

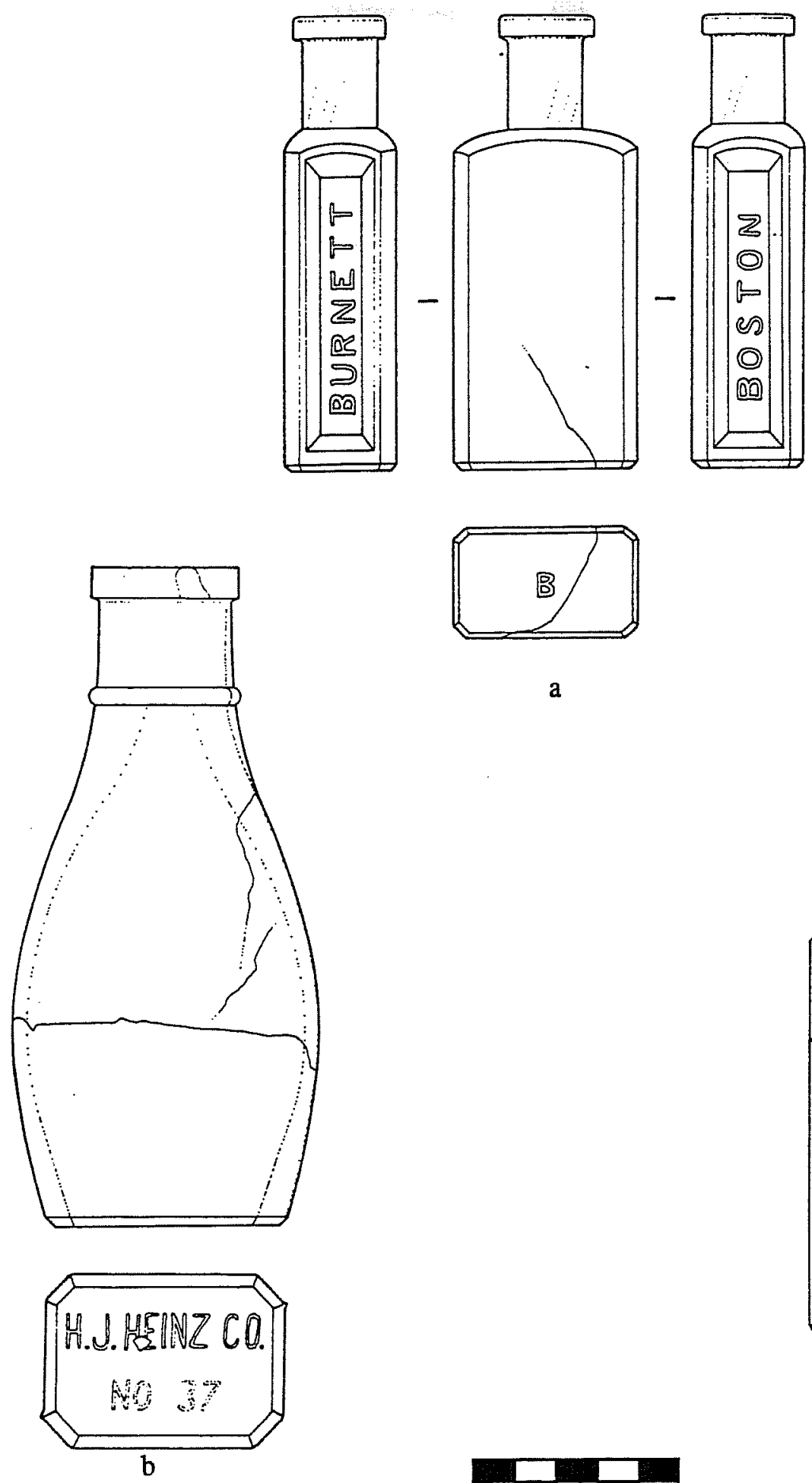

a
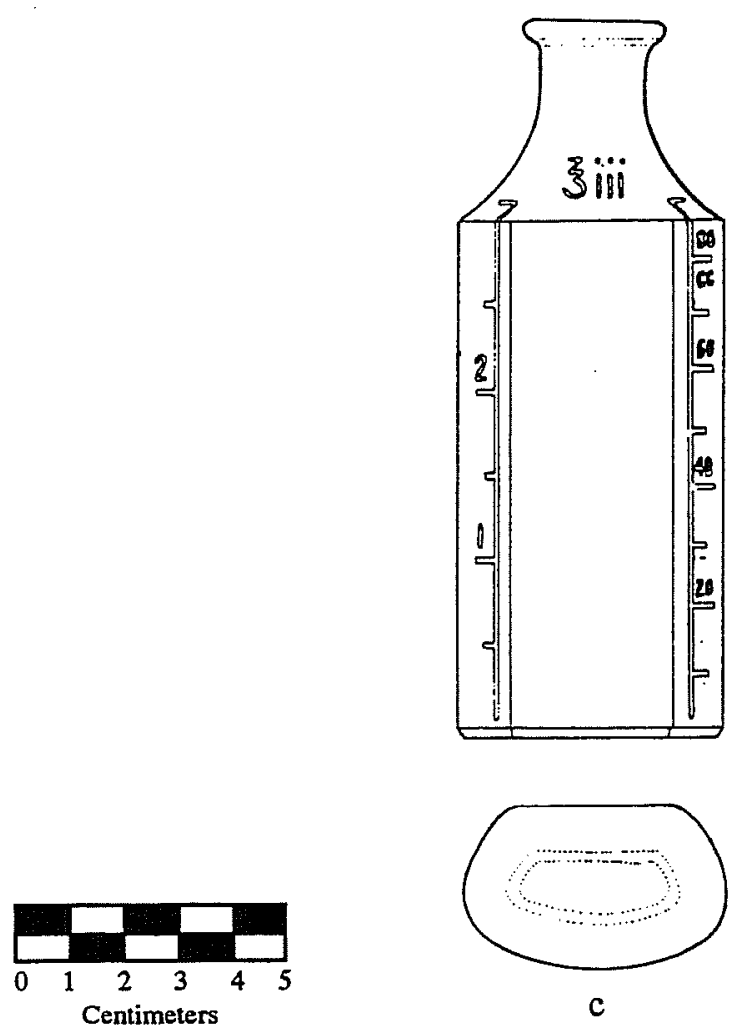

Figure 17. Whole bottles. a. Bottle \#5, clear, medicine, "BURNETT," "BOSTON;" b. Bottle \#6, clear, condiment, "H.J. HEINZ CO.;" c. Bottle \#7, clear, medicine, $1 / 2$-ounce increment markings. 


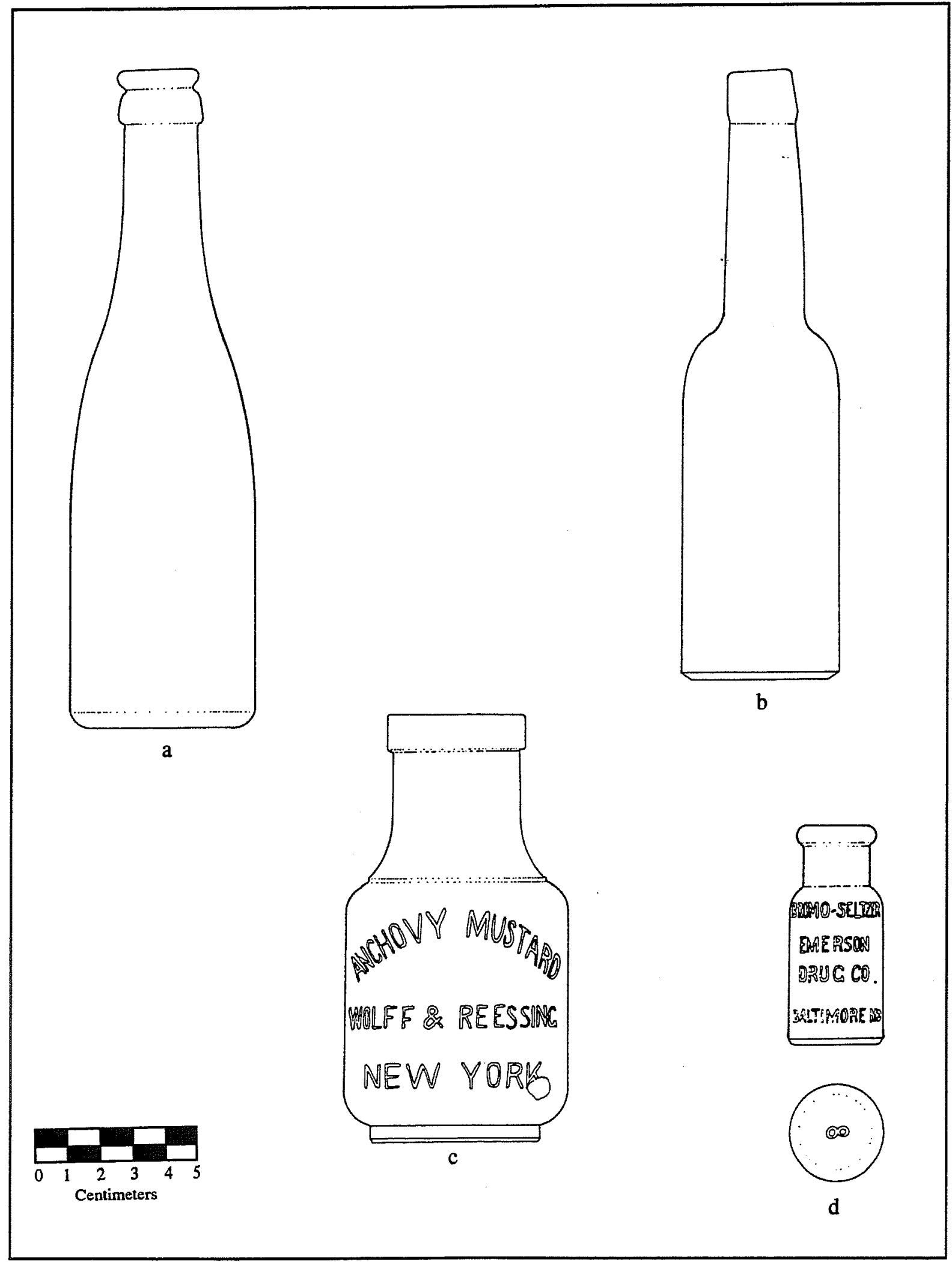

Figure 18. Whole bottles. a. Bottle \#1, dark green, beer; b. Bottle \#2, clear food or condiment; c. Bottle \#3, clear, condiment, "ANCHOVY MUSTARD;" d. Bottle \#4, cobalt blue, medicine, "BROMOSELTZER." 


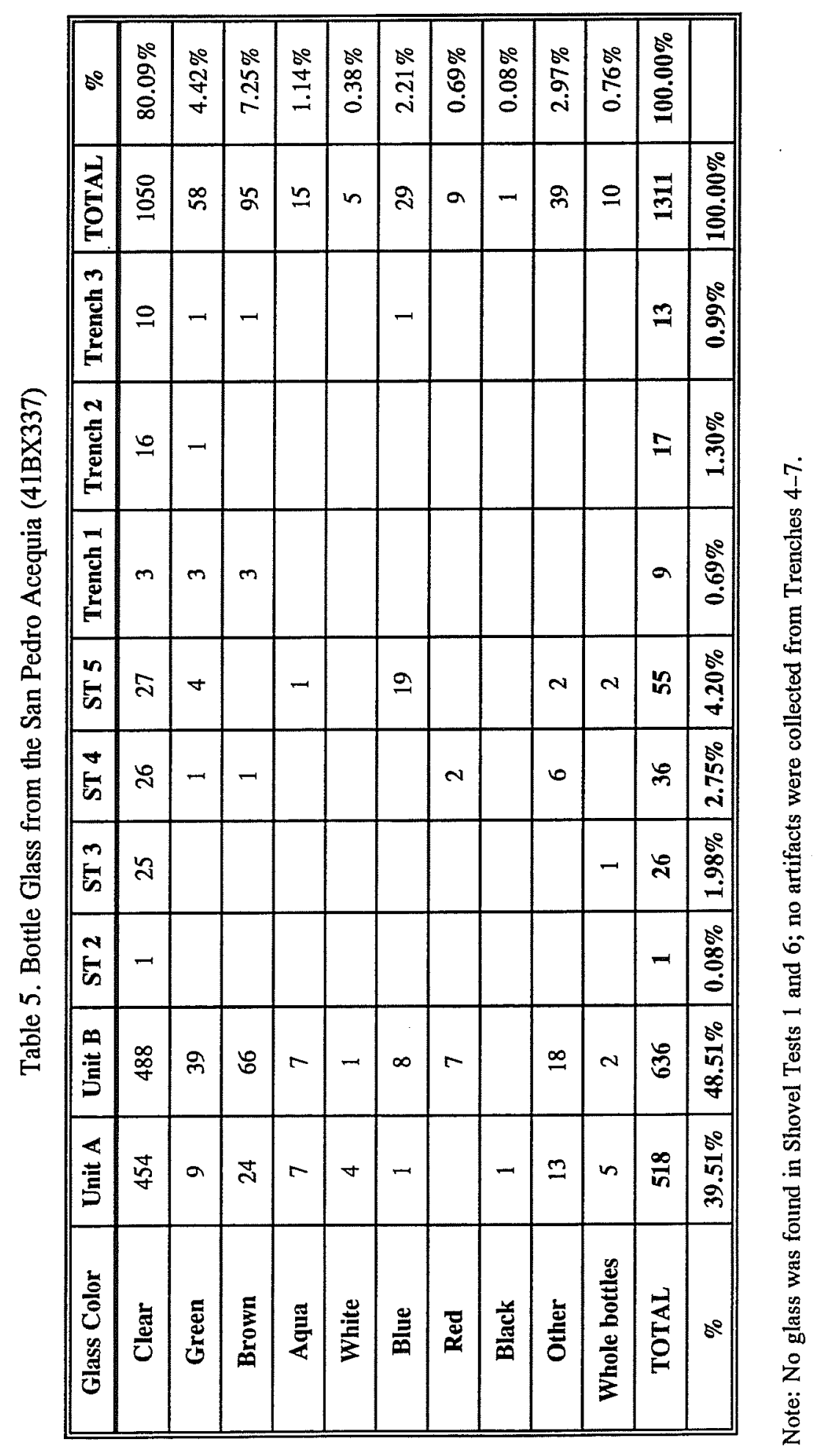




\section{Summary}

Whole bottles recovered from the San Pedro Acequia represent the period from 1880 until the ditch was filled in 1912. The predominance of clear glass fragments is also indicative of the post-1880 period.

\section{Toys, Marbles, and Dolls}

Ten fragments of pink/white porcelain bisque dolls were found during the excavation. Three of the fragments, crossmended from Units A and $B$, show facial features; a complete doll's ear is present on one mended portion. Other doll sherds are of the trunk or neck. An indecipherable mark, possibly denoting manufacturer, is present on one fragment.

Five ceramic marbles, ranging in size from $1.3 \mathrm{~cm}$ to $2 \mathrm{~cm}$ were recovered from the acequia. Four marbles are shades of natural clay, from pale gray to red clay color, and do not feature any glaze. The largest of the marbles $(2 \mathrm{~cm})$ is made of stoneware with a cobalt blue glaze. This type, called Bennington, was manufactured in Germany ca. 1875-1915 (Zapata 1996:107).

Other toys found in the acequia include a white porcelain doll's tea cup, and a miniature metal hoe. This category represents .31 percent $(n=17)$ of the total artifact assemblage.

\section{Clothing And Personal Items}

Clothing and personal items represent .52 percent $(n=29)$ of the artifacts recovered from the acequia. These include 19 buttons, seven of which are metal, the other 12 bone and plastic. One button was identified as a shoe button. Also included are one hook, four snaps, an eyelet, and a snuff can. The metal buttons and the snuff can are too corroded to be dated.

\section{Household Items}

Twenty various household items, comprising 0.36 percent of the artifactual record, were processed.

\section{Light Source-related Items}

Light source-related artifacts include a clear glass oil lamp base and clear glass chimney, arc light carbons, light bulb fragments, and a bicycle lamp.

Carbide Bicycle Lamp. The bicycle lamp (Figure 20 ) is constructed of two separate white metal pieces. The larger main portion (Figure 20a) provided fuel storage and has an iron bracket for attachment to the bicycle; the reflector portion (Figure 20b) fitted onto the upper section of the fuel-storage chamber and directed the flame beam forward. The reflector was fitted with two circular, two-centimeter-diameter glass inserts, one red and one green. Red lights are conventionally used to signify the port, or left, side; green lights indicate the starboard, or right, side.

As the bicycle lamp was being photographed under magnification, a manufacturer's mark was discovered on the front of the fuel storage chamber: ". . MFG, CHICAGO." The mark, though nearly unintelligible, made it possible to locate an identical carbide bicycle lamp in the 1902 Sears, Roebuck catalog. The lamp is described in detail in the catalog (Sears, Roebuck 1902: 284):

The Columbia Automatic Gas Lamp . . . This lamp is positively automatic. The size of flame can be instantly regulated by a gas valve, and it is impossible to flood the carbide chamber with water. On that account it is more economical than others, and the carbide charge can be repeatedly used until entirely exhausted. Having a large lens, a parabolic reflector, a long candle 

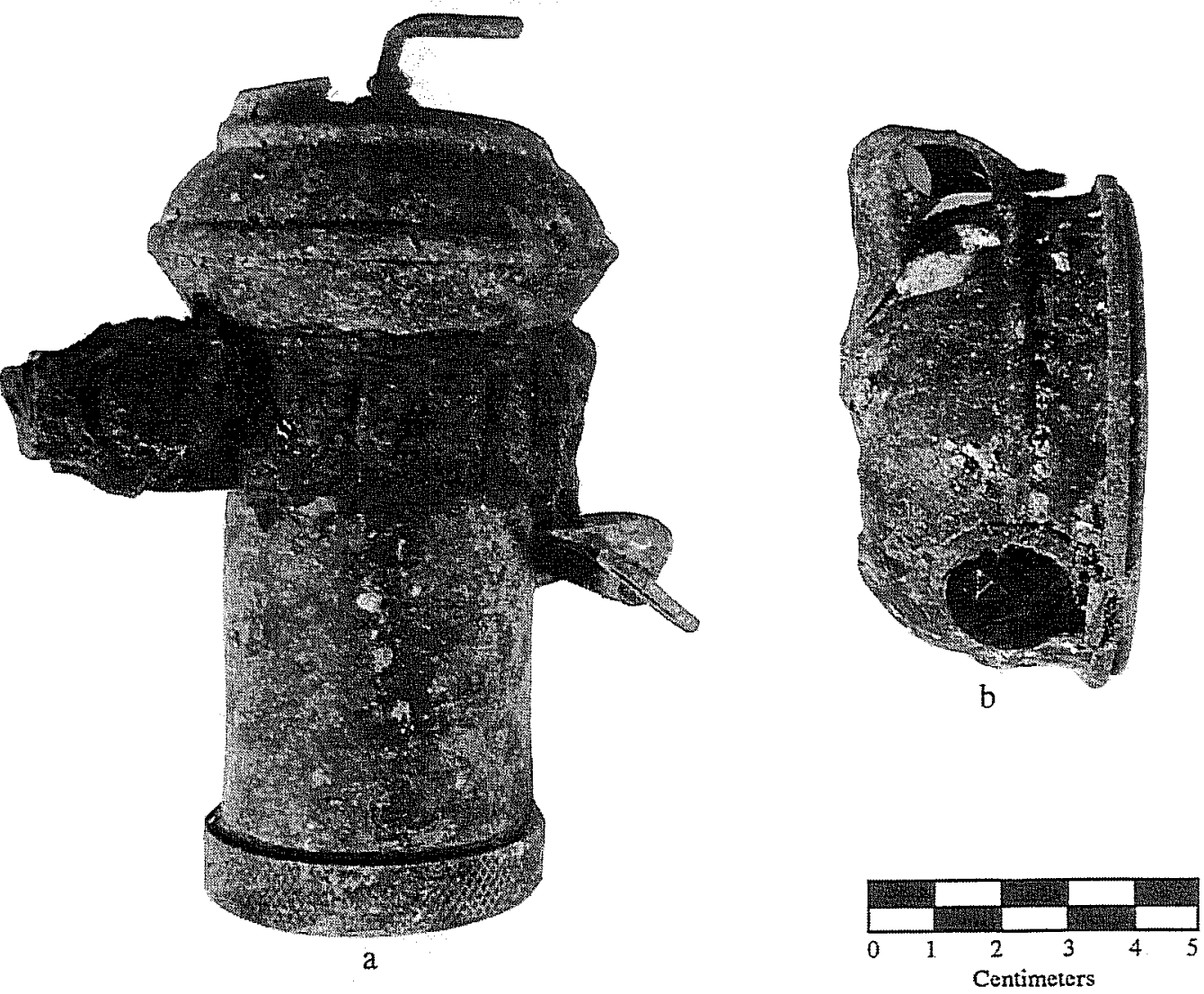

Figure 19. Carbide bicycle lamp. a. main portion; b. reflector.

flame, it is able to throw a most powerful stream of light. The bracket accompanying every lamp is adjustable to every possible degree, and enables the rider to attach lamp to either fork or steering head.

No. 19R339 Columbia Automatic Gas Lamp.

Price, each . . . . . (Postage extra, 28 cents) . . . . \$1.29

The main part of the carbide bicycle lamp recovered from the acequia (Figure 20a) measures $14 \mathrm{~cm}$ in height and $11.5 \mathrm{~cm}$ in width, the reflector portion (Figure 20b) measures $8.5 \mathrm{~cm}$ in diameter.

\section{Miscellaneous Household Items}

Other household items include a flatware knife, a key, latch door hooks, iron brackets, a metal wheel which probably attached to a furniture leg for mobility, and a wall hook. All metal objects are in badly corroded condition.

\section{Activities}

Writing materials were the only activities-related items found $(n=5, .09$ percent). These include a slate pencil and four pencil leads.

\section{Barn And Workshop Items}

Barn and workshop items $(n=14)$ made up 0.3 percent of the artifact collection. An interesting tool recovered from the San Pedro Acequia was a large $(31 \times 13.5 \mathrm{~cm})$ iron pulley. Nine short segments of wire and barbed wire, three metal hooks, and a link of chain were also found. No other items that could be identified as tools were recovered. 


\section{Construction Materials}

Construction materials is the largest category of artifacts taken from the acequia $(n=2,225)$, 40.96 percent of the total artifact count. The bulk of these materials came from Unit A, secondarily from Unit B, and then Shovel Test 5. Cut nails $(n=1,262)$ account for the majority of the artifact count, followed by wire nails $(n=623)$; wood fragments $(n=119)$; window glass $(n=98)$; brick $(n=55)$; and various other building materials.

Hand-forged nails were manufactured in the U.S. until around 1850 , when cut (or square) nails began to be made. Wire nails were introduced around 1890 (Fox et al. 1989:48), making initial construction dates for the housing on the site consistent with the 1884 date indicated by $\operatorname{Cox}(1986: 12)$.

Among the construction materials were three segments of cedar posts used in the wood lining of the acequia. Two of these post fragments were found in Unit B (see Figure 9), and another in Trench 7. These posts are likely all that remain of repairs performed in 1881-1882 by recommendation of the city engineer, Charles $P$. Smith, and the ditch commissioner, B. Wilkins.

Other construction items include a three-piece hinge of very thin metal with three nail holes; an O-ring; a metal bracket; chunks of mortar; and a brick fragment, possibly adobe.

\section{Utilities-related Items}

Materials used specifically for the purpose of utility construction-electric, water, or gaswere classified in a separate category. Thirty utilities-related artifacts were found, including sections of water pipes, ceramic sewer tiles, plastic insulation material, and a pipe joint.

\section{Arms-related Items}

Three brass bullet shell casings were recovered. Two were identified as .22 caliber, and one as .38 caliber.

\section{Organic Materials}

Faunal remains comprise the majority of the organic material recovered from the acequia. The faunal analysis is presented in the following section. Other organic materials recovered include numerous eggshell fragments, mussel shells, marine shells, and one charred seed.

\section{Miscellaneous Items}

Most miscellaneous items are fragments of unidentifiable metal, including two pieces which were fused onto rocks from burning. One piece of metal is about $20 \mathrm{~cm}$ in length, twisted like a corkscrew, and is probably lead. Also included in this category are five rubber discs of unknown function. A thin metal tag, about $3 \mathrm{~cm}$ in length, has embossed lettering that is almost indecipherable. It reads "DAL . . ." at the top; and "DA . .." at the bottom. The function of this tag is unknown.

\section{Items Weighed, Not Counted}

A total of 5,411.84 grams of weighed, not counted material was processed This category includes amorphous scrap metal, charcoal, and coal. The largest concentration of scrap metal $(2,461.7 \mathrm{~g})$ was found in Unit B, concentrated at the $80-90 \mathrm{~cm}$ bs level. In addition, a large amount of scrap metal $(2,289.3 \mathrm{~g})$ occurred in Unit A, mostly at the $70-80 \mathrm{~cm}$ bs level. Neither concentration was in a context that would suggest an on-site manufacturing activity, both are considered trash deposits. The largest concentration of charcoal and coal occurred in the vicinity of Shovel Test 5 . 


\begin{abstract}
Summary
Most of the artifacts from the San Pedro Acequia are construction materials and post-usage household items. These artifacts were deposited in the acequia after 1859 , and most likely after 1884, but before ca. 1912. No artifacts belonging to the eighteenth century or early nineteenth century were found. The absence of artifacts from earlier time periods is attributed to the cleaning and preservation of the irrigation channels periodically over the years until the early twentieth century.
\end{abstract}

Houses were constructed in the vicinity in 1884 ; until that time, the land was agricultural (Cox 1986:12) and artifact deposition would not have been likely. The acequia fell into disuse soon after 1900 and became a residential dump site, as revealed by the types of articles recoveredkitchenwares, toys, personal items, etc. It became practical to dump broken household wares, tin cans, and kitchen remains into the acequia canal when it was no longer used for irrigation purposes. The large quantity of clear, unembossed bottle glass is indicative of post1880s manufacture and deposition. The large quantity of scrap metal implies post-1900 deposition, as does the assortment of ceramics. Some artifacts were burned, probably in trash fires after being deposited in the ditch. 


\section{Faunal Analysis \\ Barbara A. Meissner}

Animal bone recovered from past excavations of the acequias in San Antonio has generally been treated with cursory observation. A more detailed documentation is presented in an attempt to add to a growing CAR database representing early twentieth century culture and diet in San Antonio. Table 6 reflects a Number of Individual Specimens (NISP) distribution not uncommon to depositions found elsewhere in buried privies and acequias in San Antonio. Appendix A provides more detailed descriptions and proveniences.

\section{Results}

In all, 959 vertebrate animal remains were recovered, with a total weight of $1,277.53 \mathrm{~g}$. The bone was identified to the genus and/or species level when possible, using the comparative collection at the CAR laboratory and standard texts on faunal identification (Hillson 1986; Gilbert 1990; Olsen 1964, 1968). The Number of Identified Specimens in this collection was 123 (12.83 percent). Table 6 lists species identified; information in the Notes column concerning diet and habits of wild animals are from Burt and Grossenheider (1976).

The collection includes fragments as well as whole bones of 11 different species of mammals, four birds, and a reptile. No fish bones were recovered. Of the 123 identifiable bones, mammals are represented by 46 cattle (37.4 percent), 21 rat (17.07 percent), 12 pig (9.75 percent), 7 cat (5.69 percent), 3 dog or coyote (2.44 percent), 1 opossum (0.81 percent), 1 squirrel (0.81 percent), and 1 raccoon $(0.81$ percent). Birds are represented by 14 duck (11.38 percent), 6 chicken (4.88 percent), 6 dove or pigeon ( 4.88 percent), and 2 turkey bones ( 1.63 percent). The lone reptile bone is that of a snake ( 0.81 percent).

\section{Discussion}

Over 72 percent of the bones recovered are from animals considered to be food resources. Cattle bones were the most prevalent, suggesting they were a major part of the diet. Those animals that are represented but not generally regarded as food sources are dogs or coyotes, cats, rats, opossum, and snake (27.44 percent). Even though almost one-fifth (17.07 percent) of the bones were from rats, that quantity may be under-represented due to loss during screening through $1 / 4$-inch mesh. The large number of rats were likely attracted by unsanitary conditions in a relatively undeveloped area. The absence of fish bones may also be due to loss during screening, or may suggest that the acequia's polluted waters could not support them. The opossum, squirrel, rabbit, raccoon, and dove or pigeon bones may represent hunting activities. The two .22 caliber shell casings recovered represent a small arms suitable for killing small mammals. 
Table 6. Species Identified During Analysis

\begin{tabular}{|c|c|c|c|c|}
\hline Taxon & $\begin{array}{l}\text { Common } \\
\text { Name }\end{array}$ & NISP & $\begin{array}{l}\text { \% of } \\
\text { Total }\end{array}$ & Notes \\
\hline Mammalia & \multicolumn{4}{|l|}{ Mammals } \\
\hline Bos taurus & Cattle & 46 & 37.40 & \\
\hline Sus scrofa & Domestic pig & 12 & 9.75 & \\
\hline Canis sp. & Dog/Coyote & 3 & 2.44 & $\begin{array}{l}\text { Differentiation of these canids is difficult. } \\
\text { The size of these bones could be either. }\end{array}$ \\
\hline Felis domesticus & House cat & 7 & 5.69 & Probably a single individual. \\
\hline Pracyon lotor & Raccoon & 1 & .81 & $\begin{array}{l}\text { Nests in trees or ground burrows; largely } \\
\text { nocturnal; omnivorous; prefers to feed near } \\
\text { water. }\end{array}$ \\
\hline $\begin{array}{l}\text { Didelphis } \\
\text { marsupialis }\end{array}$ & Opossum & 1 & .81 & Nests in dens; nocturnal; omnivorous. \\
\hline Sciurus niger & Fox squirrel & 1 & .81 & $\begin{array}{l}\text { Nest in trees, forages on the ground; feeds } \\
\text { on seeds and nuts, some eggs; adapts well } \\
\text { to urban environments. }\end{array}$ \\
\hline Sylvilagus sp. & $\begin{array}{l}\text { Cottontail } \\
\text { rabbit }\end{array}$ & 2 & 1.63 & $\begin{array}{l}\text { Differentiation of } S \text {. floridansus and } S \text {. } \\
\text { audubonii is difficult; their ranges overlap } \\
\text { in San Antonio area. }\end{array}$ \\
\hline Sigmodon hispidus & Cotton rat & 10 & 8.13 & $\begin{array}{l}\text { Nests on surface or in burrows; feeds } \\
\text { largely on green plants, but will eat eggs; } \\
\text { one of the most common indigenous rats in } \\
\text { South Texas. }\end{array}$ \\
\hline Rattus rattus & Black rat & 8 & 6.50 & $\begin{array}{l}\text { Prefers to live in buildings; will eat almost } \\
\text { anything; immigrated from Europe. }\end{array}$ \\
\hline Oryzomys palustris & Rice rat & 3 & 2.44 & $\begin{array}{l}\text { Prefers marshy or riverine environments; } \\
\text { nocturnal and semi-aquatic. }\end{array}$ \\
\hline Aves & \multicolumn{4}{|l|}{ Birds } \\
\hline Gallus domesticus & Chicken & 6 & 4.88 & \\
\hline Meliagris gallopavo & Turkey & 2 & 1.63 & \\
\hline Anatinae & Ducks & 14 & 11.38 & \\
\hline Columbia sp. & Dove/Pigeon & 6 & 4.88 & \\
\hline Reptilia & \multicolumn{4}{|l|}{ Reptiles } \\
\hline Thamnophis sp. & Garter snake & 1 & .81 & $\begin{array}{l}\text { This is probably } T \text {. marcianus, the } \\
\text { checkered garter, as this is the most } \\
\text { common garter snake in the area. }\end{array}$ \\
\hline & TOTAL NISP & 123 & & \\
\hline
\end{tabular}




\section{Diatom Analysis \\ David L. Nickels}

\section{Introduction}

Diatom analysis is quite useful in determining the nature of aquatic environments. Samples taken from the San Pedro Acequia were submitted to Winsborough Consulting Services in Austin, Texas, for analysis. Barbara Winsborough's complete report is presented in Appendix B, a synopsis of her findings is given here.

Diatoms are microscopic algae which thrive within independent groups, assimilated according to water conditions including pollution, and additionally influenced by salinity and nutrients within the water. Diatom species shift in response to changes in water quality; therefore, the aquatic environment can be determined by analyzing the diatom assemblages within specific samples. The single cell of the algae has a silica wall. The silica is readily dissolved either through geochemical leaching or a metabolic process associated with high amounts of bacteria. Clean running spring water supports the growth of algae; highly polluted water dissolves any traces of algae (Winsborough, Appendix B).

\section{Field Methods}

Five soil samples were collected from within the acequia walls. Each .5-liter sample was placed in a plastic bag and labeled according to the specific provenience from which it was collected. Sample 1 (Unit B, acequia bottom, 60-62 cm bs) and Sample 5 (Unit A, acequia bottom, $65-70 \mathrm{~cm} \mathrm{bs}$ ) were submitted for analysis. These two samples were selected based on their direct association with the acequia's interior bottom. Diatoms tend to be well preserved in calcified minerals, and during excavation we noted that the bottom of the acequia demonstrated highly carbonated accretions. The other three samples were not analyzed; they were collected as backup samples, and as it turned out, the two samples selected provided sufficient results.

\section{Results}

Neither sample submitted showed any diatom remains. Instead, the analysis revealed cubes and spheres of pollen, phytoliths, fungi, and woody plant tissue. This indicates that the area immediately surrounding the acequia was a vegetated swamp or pond. The absence of diatoms indicates that either they were never present in the acequia, or that they dissolved after death (Winsborough, Appendix B).

\section{Conclusions}

Clean running water through the acequia would have supported the growth of diatoms. Later, heavily polluted water may have contained only cyanobacteria which essentially starved out all oxygen from the water, significantly increased the carbonate alkalinity, and caused the dissolution of any silica remains (Winsborough Appendix B). In other words, the analysis reveals that the acequia was a polluted body of water before it was filled in. 


\section{Conclusions and Recommendations David L. Nickels}

\section{Conclusions}

During initial construction in the early 1730 s, the acequia was simply a ditch dug into the clay and caliche. Its course invariably shifted slightly as it meandered lazily across the arching terrain between the San Antonio River and San Pedro Creek. The up-to-nine-foot wide stratigraphic layers of silts and clays attest to that. The project area was affected by the city's efforts to upgrade the acequia with stone lining during the 1850 s, as confirmed by the 1979 investigations (Frkuska 1981). The project area was once again affected by the city's efforts to channelize the waters using cedar posts and planks in the 1880s.

Analysis of the artifacts indicates that the majority of them were manufactured during the last half of the nineteenth and the beginning of the twentieth centuries. From its completion in the 1730s until its usefulness declined in the nineteenth century, the acequia was drained and thoroughly cleaned annually. Infrequent, cosmetic cleaning of the acequia during the latter part of the nineteenth century allowed artifacts deposited from that time to remain.

Finally in 1912, when the city ordered the acequia waters shut off for good, the residents took advantage of a convenient open ditch in which to deposit large amounts of refuse, and sometimes to burn it. Once the ditch was filled and covered with sediments, the acequia became a sealed capsule for post-late-nineteenth-century artifacts. Analysis of artifacts retrieved during the 1979 and current investigations validates this conclusion (Frkuska 1981:29-44).

Renovation of the San Pedro Acequia within the project area included lining it with wood. The current excavations indicate that the board siding was in fact, $1 \frac{1}{2}$-inch cedar boards, measuring 60 $\mathrm{cm}$ (probably in fact 24 inches, or two 12-inch boards) set $90 \mathrm{~cm}$ apart (probably 36 inches) with cedar poles on the exterior. Several of the posts recovered contained a single 20 penny (four-inch) square nail driven into the top center, probably to secure the scantling two-by-four. One excavation (Unit A) contained large gravels on the exterior of the siding in the old, narrowed channel of the acequia to support the sides of the wooden plank culvert.

Previous excavations on the San Antonio Housing Authority property revealed that other portions of the acequia exposed in 1979 were also wood lined; this was suspected at the time but not confirmed. In light of the present findings, a reexamination of the excavations conducted by CAR in June and November of 1979 indicates the existence of wooden lining in several areas between West Sheridan and West Johnson streets. All three phases of acequia construction (dirt, stone, wood) were present on the SAHA property, and all three were concurrently being used to channel water in the late nineteenth and early twentieth centuries (Figure 3). Water entered the property from under West Sheridan where it encountered a wooden retaining wall on its east bank; it then spread out in a wider clay bottom and dirtbanked channel, meandering to the southwest, until it once again was restricted by a cedar post and plank-lined channel varying in width from 84 to $145 \mathrm{~cm}$. The wooden channel carried it under stone bridge crossings at Calvert Street's juncture with an east-west alley, and again at a point where Calvert jogged abruptly to the south toward West Johnson Street. The wood channel carried the water another $25 \mathrm{ft}$ before the threefoot wide stone-lined portion of the acequia channeled its flow in a southwesterly direction to the corner of West Johnson and South Flores, and then south, out of the project area. 


\section{Recommendations}

Thirty-two trenches, six shovel tests and two hand-excavation units were placed within this project area. The investigations confirmed the course and construction materials used in the acequia. After determining the course of the acequia across the project area, the architectural firm of Beaty and Saunders agreed to redesign the SAHA central office building expansion so that its footprint would neither cover nor otherwise impact the acequia. The project archaeologist reviewed the plans on site with representatives from the architectural firm as well as the San Antonio Housing Authority. The redesign plan bordered the western edge of the acequia, resulting in minimum impact.

The artifact analysis substantiates late-nineteenthand early twentieth-century cultural deposition within the acequia. Further testing within this project area has little potential for obtaining more knowledge of the acequia's architecture and artifacts. Therefore no further testing is recommended. 


\section{References Cited}

Alamazan, J. A. P.

1731 Report of the Survey of the Original Town Tract of San Fernando de Bexar, 1731. Spanish Materials from Various Sources, Barker History Center, Austin.

Buck, S. M.

1980 Yanagana's Successors: The Story of the Canary Islander's Immigration into Texas in the Eighteenth Century. Reprinted by R. M. Benavides, San Antonio.

Burt, W. H., and R. P. Grossenheider

1976 A Field Guide to the Mammals of America North of Mexico. 3rd ed. Houghton Mifflin, Boston.

Chabot, F. C.

1937 With the Makers of San Antonio. Privately published, San Antonio.

Cox, I. W.

1986 Excavations of Portions of the San Pedro Acequia (41BX337) and A Search for the Arocha Acequia, San Antonio, Texas. Archaeological Survey Report, No. 161. Center for Archaeological Research, The University of Texas at San Antonio.

1991 Excavations at the McDonald Site, 41BX794, San Antonio, Bexar County, Texas. Archaeological Survey Report, No. 191. Center for Archaeological Research, The University of Texas at San Antonio.

1995 Documentation of the San Pedro Acequia (41BX337) at Trevino Street, San Antonio, Texas. Archaeological Survey Report, No. 230. Center for Archaeological Research, The University of Texas at San Antonio.

Cox, I. W., M. J. Brown, J. Hageman, and C. McKenzie

1990 Investigations at the Volbrath Blacksmith Shop (41BX786), San Antonio, Bexar County, Texas. Archaeological Survey Report, No. 188. Center for Archaeological Research, The University of Texas at San Antonio.

de Aviles, A.

1731 Carpeta de Correspondencia de la Provincias Internas por los anos de 1726 a 1731. Archivo General Nacional de Mexico, Volume 236:28. Richard Garay Collection, San Antonio.

Dial, S. W.

1992 Civilian Artifacts. In Archaeological Investigations in Alamo Plaza, San Antonio, Bexar County, Texas, 1988 and 1989. Archaeological Survey Report, No. 205. Center for Archaeological Research, The University of Texas at San Antonio.

Fox, A. A.

1978 Archaeological Investigations of Portions of the San Pedro and Alazan Acequias in San Antonio, Texas. Archaeological Survey Report, No. 49. Center for Archaeological Research, The University of Texas at San Antonio. 
Fox, A. A. and I. W. Cox

1990 Archaeological Excavations at the Alamo Acequia, Southwest Hemisfair Plaza, San Antonio, Bexar County, Texas. Archaeological Survey Report, No. 192. Center for Archaeological Research, The University of Texas at San Antonio.

Fox, A. A., I. W. Cox, L. Highley, and D. Hafernik

1989 Archaeological and Historical Investigations at the Site of the New Bexar County Justice Center in Downtown San Antonio, Texas. Archaeological Survey Report, No. 184. Center for Archaeological Research, The University of Texas at San Antonio.

Frkuska, A. J., Jr.

1981 Archaeological Investigations of the San Pedro Acequia, San Antonio, Texas. Archaeological Survey Report, No. 103. Center for Archaeological Research, The University of Texas at San Antonio.

Gilbert, B. M.

1990 Mammalian Osteology. Missouri Archaeological Society, Columbia.

Greer, G. H. and H. Black

1971 The Meyer Family: Master Potters of Texas. Trinity University Press. San Antonio.

Guilland, H. F.

1971 Early American Folk Pottery. Chilton Book, Philadelphia.

Hard, R. J., A. A. Fox, I. W. Cox, K. J. Gross, B. A. Meissner, G. Mendez, C. L. Tennis, and J. Zapata

1995 Excavations at Mission San José y Miguel de Aguayo, San Antonio, Texas. Archaeological Survey Report, No. 218. Center for Archaeological Research, The University of Texas at San Antonio.

Hillson, $S$.

1986 Teeth. Cambridge University Press, Cambridge.

Kovel, R., and T. Kovel

1986 Kovels' New Dictionary of Marks. Crown, New York.

Lehner, L.

1988 Lehner's Encyclopedia of U.S. Marks on Pottery, Porcelain, and Clay. Schroeder, Paducah, Kentucky.

Miller, G.

1980 Classification and Economic Scaling of 19th Century Ceramics. Historical Archaeology 14:1-19.

1991 A Revised Set of CC Index Values for Classification and Economic Scaling of English Ceramics from 1787 to 1880. Historical Archaeology 25(1):1-25. 
Olsen, S. J.

1964 Mammal Remains from Archaeological Sites Part 1; Southeastern and Southwestern United States. Peabody Museum, Cambridge.

1968 Fish, Amphibian, and Reptile Remains from Archaeological Sites Part I: Southeastern and Southwestern United States. Peabody Museum, Cambridge.

Polak, M.

1994 Bottles: Identification and Price Guide. First edition. Avon Books, New York.

San Antonio Express [SAE] (San Antonio, Texas)

1878 Doings of the City Dads. 10 July.

1880 The City Fathers. 22 December.

1883 Sewerage. 21 July.

City Council. 5 September.

1889 New Regime in the Saddle. 28 February

More City Pie Passed Around. 14 March.

1890 The Message in Full. 30 April.

1897 Sewers Have Been Accepted. 21 September.

1909 Picturesque North Flores Ditch Must Go. 3 December.

Sears, Roebuck

1969 The 1902 Edition of The Sears Roebuck Catalogue, edited by C. Amory. Bounty Books, New York.

Sibley, M. M.

1973 George W. Brackenridge, Maverick Philanthropist. University of Texas Press, Austin.

Thorn, C. J.

1947 Handbook of Old Pottery and Porcelain Marks. Tudor, New York.

Valdez, F., Jr., and J. D. Eaton

1979 Preliminary Archaeological Investigations of Part of the San Pedro Acequia, San Antonio, Texas. Archaeological Survey Report, No. 85. Center for Archaeological Research, The University of Texas at San Antonio.

Zapata, J.

1996 Alamodome and Abroad: A Composite Inquiry on Toy Marbles. In Archaeology at the Alamodome: Investigations of a San Antonio Neighborhood in Transition, Volume III, Artifact and Special Studies, edited by A. A. Fox and R. J. Hard. Archaeological Survey Report, No. 238. Center for Archaeological Research, The University of Texas at San Antonio. In press. 


\section{Appendix A: Faunal Remains}

\begin{tabular}{|c|c|c|c|c|c|c|c|}
\hline Unit & Level & Taxon & Count & Weight & Burned & Butchered & Notes \\
\hline ST \#2 & 1 & UID Bird & 1 & 0.23 & & & \\
\hline \multirow[t]{6}{*}{ ST \#3 } & 1 & UID Mammal & 10 & 4.24 & 1 & 2 & \\
\hline & 1 & UID Bird & 3 & 0.38 & & & \\
\hline & 2 & UID Bird & 1 & 0.38 & & & \\
\hline & 2 & UID Mammal & 7 & 10.14 & & 4 & \\
\hline & 3 & Columbia sp. & 1 & 0.21 & & & \\
\hline & 3 & UID Bird & 1 & 0.02 & & & \\
\hline \multirow[t]{8}{*}{ ST \#4 } & 1 & UID Mammal & 2 & 1.96 & & 2 & \\
\hline & 2 & UID Mammal & 5 & 0.68 & 1 & & \\
\hline & 3 & S. hispidus & 1 & 0.46 & & & \\
\hline & 4 & Canis sp. & 1 & 0.48 & & & \\
\hline & 4 & UID Mammal & 27 & 31.66 & & 6 & \\
\hline & 4 & D. marsupialis & 1 & 0.10 & & & \\
\hline & 5 & UID Mammal & 2 & 0.62 & & & \\
\hline & 6 & UID Mammal & 1 & 1.91 & & & \\
\hline \multirow[t]{7}{*}{ ST \#5 } & 1 & UID Mammal & 16 & 21.54 & 5 & 2 & \\
\hline & 1 & S. scrofa & 1 & 2.67 & & & \\
\hline & 1 & B. taurus & 1 & 106.17 & & & \\
\hline & 2 & S. niger & 1 & 0.18 & & & \\
\hline & 2 & UID Mammal & 11 & 11.13 & 8 & 1 & \\
\hline & 3 & UID Mammal & 15 & 7.73 & 3 & 3 & \\
\hline & 3 & $R$. rattus & 1 & 0.26 & & & \\
\hline \multirow[t]{2}{*}{ Trench 3} & & B. taurus & 2 & 16.58 & & 2 & \\
\hline & & UID Mammal & 2 & 16.96 & & 2 & \\
\hline \multirow[t]{16}{*}{ Unit A } & Surf. & UID Mammal & 1 & 0.93 & & 1 & \\
\hline & 1 & UID Mammal & 41 & 17.08 & 10 & 3 & \\
\hline & 1 & UID Fish & 1 & 0.07 & & & \\
\hline & 1 & UID Bird & 1 & 0.17 & & & \\
\hline & 2 & UID Mammal & 37 & 16.25 & 3 & 5 & \\
\hline & 3 & Canis sp. & 1 & 1.69 & & & A big puppy \\
\hline & 3 & B. taurus & 2 & 15.06 & 1 & 2 & \\
\hline & 3 & UID BIrd & 1 & 0.29 & & & \\
\hline & 3 & UID Mammal & 78 & 28.15 & 14 & 16 & \\
\hline & 3 & S. scrofa & 2 & 2.61 & 2 & 2 & \\
\hline & 4 & Anatinae & 9 & 5.87 & & & \\
\hline & 4 & B. taurus & 17 & 159.05 & & 15 & \\
\hline & 4 & F. domesticus & 7 & 1.74 & & & Arthritic feet \\
\hline & 4 & G. domesticus & 3 & 2.62 & & & \\
\hline & 4 & S. scrofa & 3 & 11.33 & & 1 & \\
\hline & 4 & Sylvilagus sp. & 2 & 0.93 & & & \\
\hline
\end{tabular}




\begin{tabular}{|c|c|c|c|c|c|c|c|}
\hline Unit & Level & Taxon & Count & Weight & Burned & Butchered & Notes \\
\hline \multirow[t]{8}{*}{ Unit A } & 4 & UID Bird & 12 & 3.86 & 3 & & \\
\hline & 4 & UID Mammal & 201 & 209.12 & 21 & 48 & \\
\hline & 6 & UID Birds & 7 & 4.17 & & & \\
\hline & 6 & UID Mammal & 22 & 8.07 & 2 & & \\
\hline & 6 & UID Fish & 3 & 2.38 & & & \\
\hline & 6 & Anatinae & 5 & 4.73 & & & \\
\hline & 6 & G. domesticus & 3 & 1.54 & & & \\
\hline & 6 & S. hispidus & 6 & 1.89 & & & \\
\hline \multirow[t]{25}{*}{ Unit B } & 1 & UID Mammal & 40 & 24.74 & 6 & 6 & \\
\hline & 1 & UID Bird & 3 & 2.48 & & & \\
\hline & 2 & B. taurus & 17 & 145.40 & 1 & 15 & \\
\hline & 2 & M. gallopavo & 2 & 3.09 & & & \\
\hline & 2 & R. rattus & 5 & 0.74 & & & \\
\hline & 2 & S. scrofa & 3 & 16.01 & & 3 & \\
\hline & 2 & UID Bird & 5 & 1.67 & & & \\
\hline & 2 & UID Fish & 3 & 0.25 & & & \\
\hline & 2 & UID Mammal & 139 & 135.06 & 6 & 26 & \\
\hline & 3 & UID Mammal & 36 & 38.63 & 4 & 13 & \\
\hline & 3 & UID Fish & 2 & 0.35 & & & \\
\hline & 3 & O. palustris & 3 & 0.49 & & & $M N I=2$ \\
\hline & 3 & B. taurus & 2 & 23.15 & & & \\
\hline & 4 & B. taurus & 5 & 39.26 & & 4 & \\
\hline & 4 & Canis sp. & 1 & 0.99 & & & A puppy \\
\hline & 4 & Columbia sp. & 5 & 1.36 & & & \\
\hline & 4 & P. lotor & 1 & 0.10 & & & \\
\hline & 4 & R. rattus & 2 & 0.42 & & & \\
\hline & 4 & S. hispidus & 3 & 1.03 & & & \\
\hline & 4 & S. scrofa & 3 & 7.82 & & 1 & \\
\hline & 4 & Thamnophis sp. & 1 & 0.09 & & & Probably marcianus \\
\hline & 4 & UID Bird & 13 & 7.24 & & & \\
\hline & 4 & UID Mammal & 84 & 90.06 & 4 & 41 & \\
\hline & 4 & UID turtle & 2 & 0.81 & & & \\
\hline & & Totals & 959 & 1277.53 & 95 & 226 & \\
\hline
\end{tabular}




\title{
Appendix B \\ Diatom Analysis of Material from the San Pedro Acequia
}

\author{
Barbara M. Winsborough \\ Winsborough Consulting \\ Austin, Texas $\mathbf{7 8 7 5 6}$
}

\section{Introduction}

Diatoms are microscopic, single-celled algae with a silica cell wall. Each diatom species has its own specific preferences and restrictions with regard to habitat, substrate, salinity, nutrient and pollution levels, current, light, depth, temperature, and moisture (Lowe 1974; Round 1981). Because of their individual environmental preferences and requirements, diatoms can provide information about the aquatic environment at the time the sediments were deposited. Diatoms are sensitive monitors of water quality, and changes in the composition of the assemblage are related to changes in climate, local hydrological regime, or land use.

Holocene marsh and lake deposits associated with archaeological sites in Texas and adjacent areas often contain diatoms (Hohn 1975; Hohn and Hellerman 1961; Lohman 1935; Meltzer 1991; Patrick 1938; Winsborough 1988, 1995). Diatoms are one of the most common and diverse plant groups to colonize mineral deposits associated with carbonate-rich spring water, including tufa, travertine, and calcified build-ups lining canals (acequias) and associated habitats (Neely et al. 1990; Winsborough et al. 1995). Because diatoms are often well preserved in these rock fabrics, this investigation was undertaken to determine if there are diatomaceous remains in the carbonate accretions associated with the San Pedro Acequia.

\section{Methods}

Two samples of the calcareous San Pedro Acequia lining were processed. These are 1) 41BX377 Unit B, Sample \#1, acequia bottom, 60-62 cm below surface (bs); and 2) 41BX377 Unit A, Sample \#5, acequia bottom, $65-70 \mathrm{~cm}$ bs. Samples were heated in hydrogen peroxide and then nitric acid, followed by washing in distilled water until clear of acid residue. They were then mounted on glass slides with Hyrax, a resin with a high refractive index. Slides were scanned and every diatom cell was recorded.

\section{Results and Discussion}

The two samples examined are entirely devoid of any remains of diatoms. There are, however, dense concentrations of small spheres about 0.4-0.5 micrometers in diameter, and small, individual cubes about 4 micrometers in diameter. These cubes are sometimes rounded in shape and form clusters. It is likely that these spheres and cubes represent bacterial precipitation of iron pyrite, or associated mineral species. The samples contain pollen, phytoliths, fungi, and woody plant tissue, suggesting that the habitat was an aquatic, vegetated area, perhaps a marsh or pond. The absence of diatoms can mean that they were never living there or that their silica shells were dissolved after death of the algal cell.

If there were diatoms present in the canal, some process must have occurred to cause the diatom silica to be dissolved. Silica dissolution can occur through geochemical leaching of sediments or by 
a mechanism associated with the metabolism of certain bacteria. Diatom opal, which is amorphous hydrated silica, is particularly susceptible to dissolution after death of the organism and degradation of the organic components of the cell. Dissolution of diatoms may be taking place in the ecological zone where dissimilatory sulfate reduction by bacteria such as Desulfovibrio causes local chemical characteristics to be significantly altered, perhaps just below the sediment-water interface.

Birnbaum and Wireman (1984) discuss a mechanism by which diatom silica is dissolved during metabolically mediated $\mathrm{pH}$ excursions up to over $\mathrm{pH} 9.7$ by Desulfovibrio. An initial increase in $\mathrm{pH}$ leading to silica dissolution is attributed to the release of ammonia during proteolysis. Desulfovibrio then releases carbon dioxide and sulfide ions which lowers the $\mathrm{pH}$ and increases carbonate alkalinity in the localized environment surrounding the bacterial cells, thereby causing precipitation of silica.

\section{Conclusions}

A canal carrying clean spring water almost assuredly would have supported the growth of at least some species of diatoms. It is quite possible, however, that if the water was heavily polluted, cyanobacteria may have been the dominant, and perhaps the only, class of microorganisms represented in the surface mat or biofilm of the canal. Support for the assumption that there was bacterial sulfate reduction comes from the acid insoluble residue. The residue contains phytoliths, pollen, and small spheres and clusters of spheres resembling pyrite framboids, probably bacterial in origin. The presence of large numbers of pyrite framboids suggests that there may have been a steep gradient in oxygen concentration near the sediment-water interface, or even in the water column itself, such that if there were any diatoms they were dissolved.

\section{References Cited}

Birnbaum, S. J., and J. W. Wireman

1984 Bacterial Sulfate Reduction and pH: Implications for Early Diagenesis. Chemical Geology 43:143-149.

Hohn, M. H.

1975 The Diatoms. In Late Pleistocene Environments of the Southern High Plains, edited by F. Wendorf and J. J. Hester, pp. 197-200. Fort Burgwin Research Center, Ranchos de Tao, New Mexico.

Hohn, M. H., and J. Hellerman

1961 The Diatoms. In Paleoecology of the Llano Estacado, edited by F. Wendorf, pp. 98-104. Fort Burgwin Research Center, Ranchos de Taos, New Mexico.

Lohman, K. E.

1935 Diatoms from Quaternary Lake Beds Near Clovis, New Mexico. Journal of Paleontology 9:455-459. 
Lowe, $\mathrm{R}$.

1974 Environmental Requirements and Pollution Tolerance of Freshwater Diatoms. EPA-670/4-74005. U.S. Environmental Protection Agency, Cincinnati.

Meltzer, D. J.

1991 Altithermal Archaeology and Paleoecology at Mustang Springs, on the Southern High Plains. American Antiquity 56:236-267.

Neely, J. A., S. C. Caran, and B. M. Winsborough

1990 Irrigated Agriculture at Hierve el Agua, Oaxaca, Mexico. In Debating Oaxaca Archaeology, edited by J. Marcus, pp. 115-189. Anthropological Papers, University of Michigan Museum of Anthropology, Ann Arbor.

Patrick, R.

1938 The Occurrence of Flints and Extinct Animals in Pluvial Deposits Near Clovis, New Mexico. Part V, Diatom Evidence from the Mammoth Pit. Proceedings of the Academy of Natural Sciences of Philadelphia 40:15-24.

Round, F. E.

1981 The Ecology of the Algae. University Press, Cambridge.

Winsborough, B. M.

1988 Paleoecological Analysis of Holocene Algal Mat Diatomites Associated with Prehistoric Wells on the Texas High Plains. 22nd Annual Meeting of the South-Central Section of the Geological Society of America. Lawrence, Kansas.

1995 Diatom-Based Paleoecological Analysis of the Late Quaternary Valley Fill. In Late Quaternary Valley Fills and Paleoenvironments of the Southern High Plains, edited by V. Holiday. Memoire of the Geological Society of America. In press.

Winsborough, B. M. , S. C. Caran, J. A. Neely, and S. Valastro, Jr.

1995 Calcified Microbial Mats Date Prehistoric Canals-Radiocarbon Assay of Organic Extracts from Travertine. Journal of Geoarchaeology. In press. 